\title{
Trade treaties and patent policy: searching for a balanced approach
}

\author{
[updated and revised 12 November 3014] \\ originally presented at the
}

\section{5th International Schumpeter Society Conference Friedrich Schiller University, Jena, Germany 27-30 July 2014}

\author{
Hazel V J Moir \\ EABC-ANUCES Visiting Fellow \\ and \\ Adjunct Associate Professor \\ Research School of Social Sciences \\ College of the Arts \& Social Sciences \\ The Australian National University \\ Canberra, Australia \\ hazel.moir@anu.edu.au
}

30-June 201412 November 2014

(C) 2014 - commercial rights reserved. Citation encouraged, but this is a draft paper so please check for final. Any comments or criticisms warmly welcomed. 


\title{
Trade treaties and patent policy: searching for a balanced approach
}

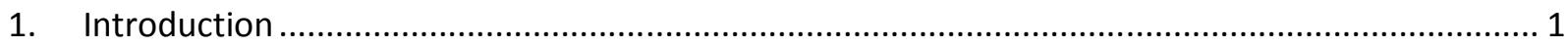

2. Key elements of a balanced patent policy design ...................................................................... 2

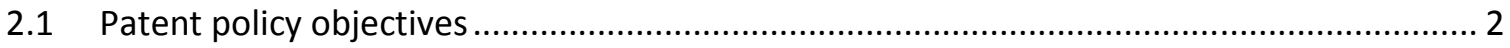

2.2 Limitation to technological innovations ........................................................................... 3

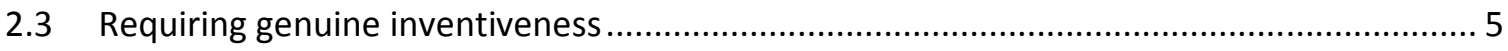

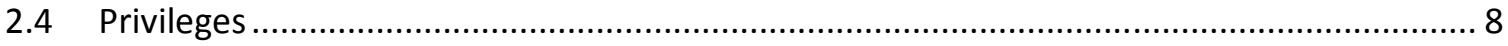

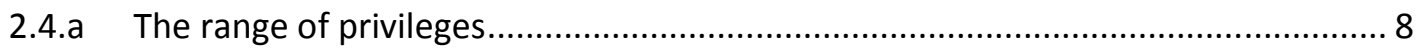

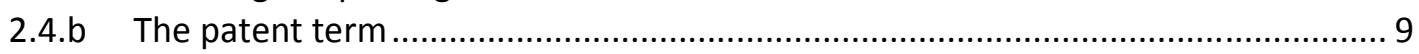

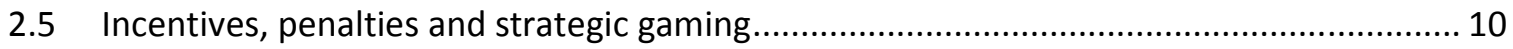

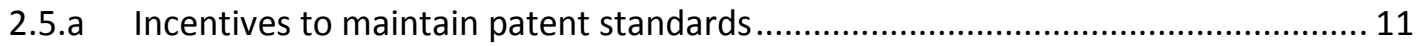

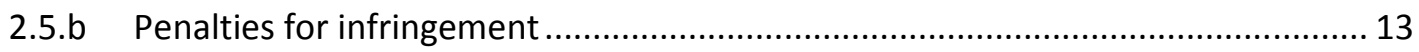

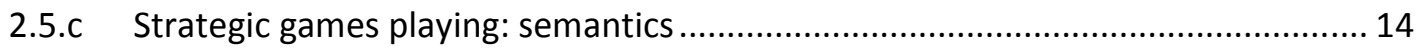

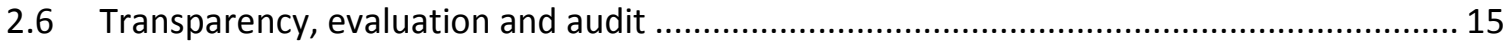

2.6.a Collect data on the impact of patents ................................................................. 16

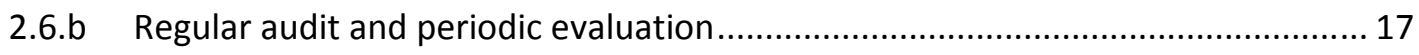

3. Comparison with TRIPS and with USTR demands.................................................................... 18

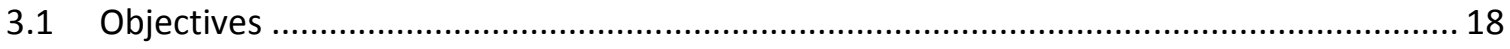

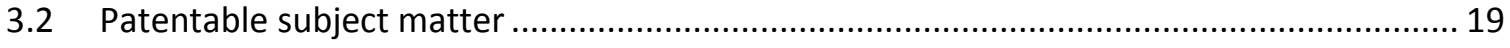

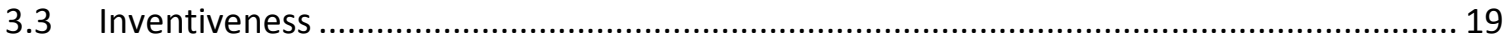

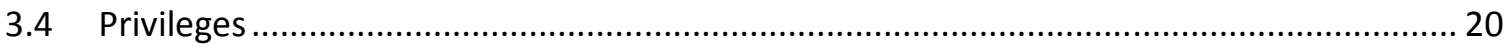

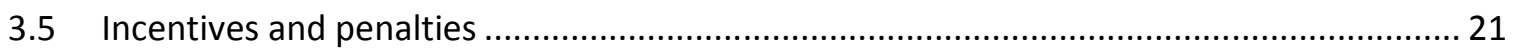

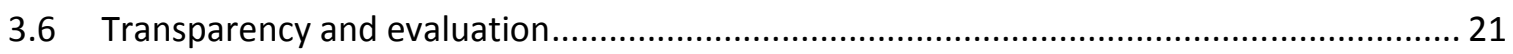

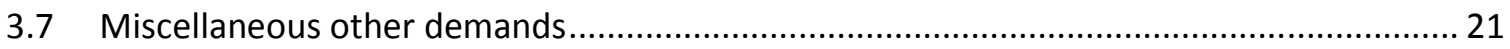

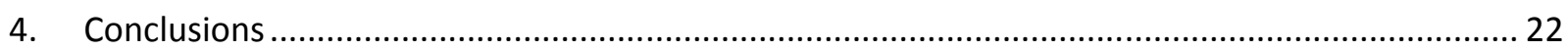

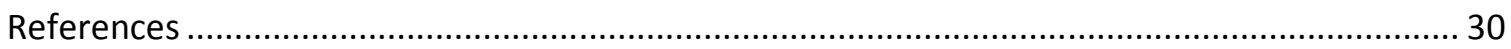

\begin{abstract}
Patents were originally designed to encourage technological innovation, which would not otherwise occur, and which create spillover benefits. Careful design is needed to ensure patents do not provide windfall benefits to inventions which would take place absent patents. Further, for the grant of a patent to be economically rational the patented invention must have a reasonable probability of providing spillover (dynamic growth) benefits that exceed monopoly (static inefficiency) losses. This paper draws on the substantial empirical research on industrial innovation and how patent systems work in practice to develop a first-best set of policy parameters for a balanced (parsimonious) patent system. That is, it attempts to design a set of parameters which maximise dynamic growth benefits while minimising static efficiency losses, thus complying with TRIPS Article 7. These parameters are compared with TRIPS and with the TRIPS-Plus elements which the USA is seeking from bi-lateral and regional trade treaties. The resulting schema allows a clearer view of the cost of patent policy provisions in "trade" treaties.
\end{abstract}




\section{Trade treaties and patent policy: searching for a balanced approach}

\section{Introduction}

Patent policy is economic policy. But most policy change comes either through trade negotiations or from judicial decisions, imported without any economic assessment into statute law. This does not augur well for soundly based policy. The key tenets for robust policy designed in the national interest are solid objective evidence and open and transparent evaluation processes. Neither of these conditions characterise patent policy changes, particularly since these have been drawn within the purview of the World Trade Organisation (WTO).

Through a series of bilateral preferential trade agreements, mostly with close allies and small economies, ${ }^{1}$ the USA is pursuing an aggressive "intellectual property" agenda exchanging improved market access for TRIPS-Plus monopoly protections. More recently the European Union (EU) joined with the USA to promote the Anti-Counterfeiting Trade Agreement (ACTA). This plurilateral agreement is unlikely to proceed, as the European Parliament overwhelmingly voted against ratification. ${ }^{2}$ In addition to substantive concerns about the lack of balance in the ACTA proposals, the negotiations were carried out in considerable secrecy. This secrecy is continued in the current Trans-Pacific Partnership Agreement (TPPA) negotiations. Despite this, leaked drafts of the proposed IP chapter show that the US continues to push a TRIPS-Plus agenda, strongly favouring rights-holders and going far beyond current US law and practice (Flynn et al. 2012).

Much of the response to these negotiations has been reactive, with a range of civil society organisations actively analysing the proposals and commenting on the problems they raise. There have also been a small number of more proactive proposals addressing the issue of what an appropriate reform agenda would be if developed from the viewpoint of maximising public welfare. The Washington Declaration of 2011 places intellectual property rights firmly in the context of serving societal goals. Though brief, it focuses on a positive agenda and, in respect of patents states:

"In a period of rapid technological change, the patent system has serious problems. In some industries, very low patenting standards and a proliferation of patents of questionable validity have fueled a culture of competition by intimidation and litigation, rather than innovation. Even when patentability requirements are applied strictly, the international patent system has become too rigid and too unitary to accommodate the diverse needs of a complex world. A more effective and manageable system for fostering technological and scientific innovation should be built around a more diverse structure of incentives for innovation." ${ }^{3}$

The Global Congress on Intellectual Property and the Public Interest then called for alternative incentives to induce needed inventions; limiting patent grants that are not justified by net benefits to the public; ensuring that inventions that are publicly funded are available for public use, ensuring meaningful research exemptions and promoting transparency in ownership and licensing.

The Max Planck Institute has also encouraged the bringing together of relevant experts to develop a more proactive approach to resisting TRIPS-Plus agendas (Ruse-Khan 2014). The specific recommendations are, however, phrased very broadly, and rely heavily of countries involved in trade negotiations to develop all the detail of a more pro-active agenda. Effectively it amounts to a simple exhortation for countries to develop more balanced patent policies.

This paper draws on the substantial research on industry economics that throws light on the role that patents do - and do not - play in creating incentives for invention and innovation. There is a massive

\footnotetext{
1 Jordan 2000; Singapore 2003; Australia 2004; Bahrain 2004; Chile 2004; Morocco 2004; Colombia 2006; Oman 2006; Panama 2007; Peru 2007; and Korea 2007. These eleven countries account for only 8.5 percent of US trade, mostly accounted for by the three high-income countries Australia, Korea and Singapore (Flynn et al. 2012: 109-110).

${ }^{2}$ There were 478 votes against ratification, 39 for and 165 abstentions (see Monica Horten, "Wow what a scorcher! ACTA slaughtered 478 to 39", IPtegrity.com, 4 July 2012 (http://www.iptegrity.com/index.php/acta/781-wow-what-a-scorcher-actaslaughtered-478-to-39).

${ }^{3}$ Global Congress on Intellectual Property and the Public Interest, August 25-27, 2011, The Washington Declaration on Intellectual Property and the Public Interest, http://infojustice.org/wp-content/uploads/2011/09/Washington-Declaration-Print.pdf pp3-4.
} 
internal contradiction in the patent system. The mechanism used as an incentive for more invention operates by suppressing the dissemination of new technology. This tension points to a fundamental principle - patent privileges should only be granted to induce inventions that would not otherwise occur and only for those that provide spillover benefits greater than their static efficiency loss. If neither the inducement effect nor the net welfare benefit effect is present, then there is no rational basis for grant of a patent. In essence an effective patent system is a parsimonious patent system.

A parsimonious patent system - one that ensures that dynamic efficiency gains exceed static efficiency losses and minimises windfall gains - would suit any country at any level of development. Indeed it would suit any nation better than the TRIPS system, and very much better than TRIPS-Plus proposals. The design presented here covers: patent policy objectives; patentable subject matter; the inventive step; the privileges provided by patents; incentives, penalties and strategic gaming; and transparency issues particularly oversight, evaluation and audit. These are put forward as policy principles. Once developed and agreed they can be translated into appropriate treaty language.

\section{Key elements of a balanced patent policy design}

\subsection{Patent policy objectives}

The traditional economic argument for the patent intervention is spelled out as a problem of fast copying. Many economists argue that industrial innovators have insufficient exclusive time in the market to recoup their development costs if competition is unrestrained. Patents are designed to overcome this alleged problem.

But fast copying alone is not sufficient to justify the patent intervention. It is because industrial innovation is widely considered to have higher social returns than private returns (ie has uncapturable spillover benefits) that the intervention becomes rational. It is generally presumed that these dynamic benefits exceed the losses from reduced competition, so that society benefits, though perhaps with a time lag. This societal goal of patent policy was emphasised in the recent Indian Supreme Court decision - the purpose of a patent system is to benefit the nation not to reward individual inventors. ${ }^{4}$ Private returns are not the issue here. Where private returns to innovation are high, patents are not needed to induce the innovation. Only where private returns are low are patents needed, but they are efficient only if spillover benefits are high enough to offset the associated static efficiency losses. This indicates an important requirement that should be included as a key policy objective.

Surprisingly, the economic objectives of patent policy are rarely mentioned in national patent legislation. They are clearly spelled out in the TRIPS Agreement:

"The protection and enforcement of intellectual property rights should contribute to the promotion of technological innovation and to the transfer and dissemination of technology, to the mutual advantage of producers and users of technological knowledge and in a manner conducive to social and economic welfare, and to a balance of rights and obligations."

(TRIPS, Article 7)

Article 7 thus provides a clear articulation of the principle goal of patent policy - to encourage technological innovation in a way that promotes social and economic welfare.

Patent policy was initially designed by mercantilist nations to gain a competitive edge in domestic technology development. Their early (C19th) extension to international players is, in some ways, perverse.

\footnotetext{
4 "Patent systems are not created in the interest of the inventor but in the interest of national economy. The rules and regulations of the patent systems are not governed by civil or common law but by political economy." Cited in Novartis AG v Union of India and others, Civil Appeal Nos. 2706-2716 of 2013, Supreme Court of India at 36.
} 
It is only through uncapturable spillovers in the domestic economy that a country benefits from granting patent monopolies. Without such spillovers to other innovating firms there are no dynamic efficiency gains against which to offset the static efficiency losses from reduced competition. It is not, therefore, rational to provide patent privileges for imported products unless these deliver substantial net consumer surplus. Until TRIPS, this key fact was recognised in the local working requirement.

But a preference for domestically produced goods is anathema in a free trade context. TRIPS Article 27.1 requires that patents shall be granted "without discrimination as to ... whether products are imported or locally produced." There are differing interpretations on whether TRIPS actually bans local working provisions. ${ }^{5}$ Banning the local working requirement raises significant challenges as to the underlying rationale for a patent system as it substantially undermines the quantum of dynamic efficiency benefits in the patent-granting nation.

Where a nation grants patents to goods which are imported it loses a very large part of the potential dynamic benefits that patents are meant to create. Yet it retains all the costs of reduced competition. For many nations, the majority of patents granted are granted to overseas entities. ${ }^{6}$ In such nations it is particularly important that there are very high standards for patent grant in order to minimise the losses due to granting monopoly rights to overseas entities. The next two sections of this paper discuss two important ways in which a country can achieve high standards for patent grant - limiting patents to technological inventions and requiring a high standard of inventiveness. Such changes would substantially increase the efficiency and effectiveness of the patent system.

\subsection{Limitation to technological innovations}

Patents were historically limited to technological inventions, though patent statutes rarely specify this. Germany, which undertook substantial research before designing its patent laws, has a fundamental, but unwritten, limitation to technology. ${ }^{7}$ Bakels notes that the limitation to technical inventions was always considered a rule of customary law (Bakels 2012: 42). This viewpoint is clearly stated in a 1976 decision by the German Federal Court of Justice:

"The patent system is also not conceived as a reception basin, in which all otherwise not legally privileged mental achievements should find protection. It was on the contrary conceived as a special law for the protection of a delimited sphere of mental achievements, namely the technical ones, and it has always been understood and applied in this way." 8

TRIPS Article 7 emphasises this fundamental and critical aspect of patent policy - the patent system is designed only for technological innovations. The reasons for this centre on the experimentation (and hence cost) required to develop new technological artefacts. It is these lumpy costs which underlie the view that time in the market can be too short to ensure an adequate return to the R\&D investment. In contrast, in other parts of an economy, such as business methods, the R\&D phase can frequently be limited to the idea itself. Implementation usually incurs only production costs not R\&D costs, so the argument that early competitors will undermine returns to R\&D does not withstand scrutiny. Given that it always takes competitors some time to deliver their version of the product to the market, ${ }^{9}$ where R\&D costs are low or

\footnotetext{
${ }^{5}$ The one WTO dispute on this issue was settled politically (Attaran and Champ 2002). Mercurio and Tyagi (2010) consider that local working may be allowed under TRIPS and provide a technical legal analysis of the issue. Local working was apparently one of the most contentious issues in the TRIPS negotiations and the controversy remains alive today (Thadikkaran 2013).

${ }^{6}$ For example in Australia the proportion of patents granted to overseas entities has remained stable at 92 per cent for decades. Over the period 1998 to 2012 the percentage granted to non-resident entities varied from 92 to 99 in Singapore, from 87 to 99 for Malaysia, from 93 to 99 for Vietnam, from 86 to 91 for Canada and from 85 to 93 for New Zealand (calculated from data at http://www.wipo.int/ipstats/en/statistics/country_profile/). The USA and UK are middle ranking in the dominance of foreign entities among patent holders (comparable US figures are 46 to 52 and for the UK 44 to 54). At the other end of the scale countries such as France ( 8 to 20), Germany (12 to 16) and Japan (9 to 18) have very low proportions of patents granted to foreign entities.

${ }^{7}$ Assumptions that are fundamental to agreed views on how society does and should work are so generally shared that they are rarely mentioned (Hirschman 1977: 69).

${ }^{8}$ Pilch provides this translation from the Court's 1976 Disposition Program decision (Pilch 2003: 293).

${ }^{9}$ The original empirical research demonstrating the costs and time required for copying was undertaken by Mansfield and colleagues (Mansfield et al. 1981). Their results were replicated in the larger Yale survey (Levin et al. 1987).
} 
there are network effects, first-mover advantages can be considerable and will usually be sufficient to induce the innovation without the need for a patent monopoly.

Empirical and theoretical analyses show that those inventions which may not occur absent patents are those where the initial period of market exclusivity is too short to recoup research and development (R\&D) costs. ${ }^{10}$ This will typically be discrete product inventions which are highly codified and which can therefore be imitated more quickly. The most obvious policy conclusion from this range of empirical evidence is that innovations should be patentable only in selected technologies/industries. ${ }^{11}$

The first-best option for a focussed and efficient patent system is to limit patents to highly codified inventions with large lumpy R\&D costs. This first-best option is denied by TRIPS Article 27.1.

Courts and patent offices have laboured over definitions of "technological" and "technical", with poor results. What the patent system needs is good proxies to identify inventions where substantial experimentation is required. If "technological" and "technical" are understood as proxies for this, we could achieve far more satisfactory boundaries to the patent system. This could be done by including in Explanatory Memoranda clear references to the intent to provide patents only where time in the market would not permit recoupment of R\&D costs. Another approach to delimiting the scope of patentable (technological) inventions is the traditional exceptions - inventions that do not meet either the original "manner of manufacture" or "industrial applicability" tests. As courts (and quasi-courts such at the EPO Technical Boards) have substantially diluted these two tests over time, ${ }^{12}$ the broad exceptions to what constitutes a technological invention need to be spelled out in patent statutes. However in the interests of remaining flexible for unknown future technologies it is preferable that the boundaries to what is a patentable (technological) invention are spelled out in terms of the kinds of things excluded.

Patentable inventions should not include:

- Inventions where R\&D costs are low or exclusive time in the market without patents is long;

- Discoveries - things that are not markedly different from things found in nature;

- Mathematical algorithms - there is argument as to whether mathematics is a science or an art, but it is certainly not a technology. It is a critical enabling discipline in many genuine technological areas. Software was never intended by any parliament or government to be patentable, ${ }^{13}$ and must be clearly and absolutely excluded; and

- Methods of medical treatment including diagnostic, therapeutic and surgical methods of treatment (already excludable under TRIPS). ${ }^{14}$

\footnotetext{
${ }^{10}$ Key theoretical analyses are Arrow 1962, Boldrin and Levine 2004 and Bonatti and Comino 2011. The major empirical analyses are well summarized in López 2009. For a much fuller discussion of this argument, and the range of relevant evidence see Moir 2013c: Chapter 2.

${ }^{11}$ Some argue that without patents many inventions would be kept secret. This does not hold water from an economic perspective. Boldrin and Levine (2013: 9-10) cogently argue, as others have before them, that it would be irrational to patent an invention that can be kept secret. The history of innovation shows that inventors and innovators exchange ideas as a matter of course and that secrecy, where it occurs, normally only occurs in the last stages of commercialisation.

${ }^{12}$ For example in 1959 the Australian High Court diluted the "manner of manufacture" test to a test that today is little more than the ability to make money (National Research Development Corp. v. Commissioner of Patents (1959) 102 CLR. 252).

${ }^{13}$ In the USA the 1980 Supreme Court's Diehr decision spelled a radical break in patent policy - and one that was inconsistent with advice the government had accepted from the 1966 President's Commission on the Patent System ("To Promote the Progress of ...Useful Arts" in an Age of Exploding Technology) (Diamond v. Diehr, 450 U.S. 175 (1981)). Similarly in Australia the government accepted recommendations from a 1984 patent review committee (IPAC 1984) not to extend patents to software -indeed this had bi-partisan support. This did not prevent Australian courts from subsequently making decisions which mean that all software is today patentable in Australia - indeed there is no requirement for a pretence that software is not software, as there is in the USA and Europe. Relevant decisions are Re International Business Machines Corporation v Patrick Anselm Smith, Commissioner of Patents [1991] FCA 625 (13 December 1991) and Ccom Pty Ltd v Jiejing Pty Ltd [1994] FCA 1168 (22 June 1994). In TRIPS, it was clear that software lay in the copyright area (see Article 10 and also New Zealand Ministry of Economic Development 2002).

${ }_{14}$ Only the USA and Australia allow methods of medical treatment to be patented (http://www.fbrice.com.au/publication/ Education Series - Number three Patents for Methods of Medical Treatment of Humans.aspx). In the USA there are legal provisions ensuring medical practitioners cannot be sued for infringement of such patents. There are no parallel protections for medical practitioners in Australia.
} 
Only the first of these exclusions contravenes TRIPS.

A special comment is needed in regard to granting patents for methods of using previously patented things. For example, when a patent is granted for a pharmaceutical compound, the privileges granted to the patent owner allow the prevention of all commercial uses of that compound in the market where the patent holds. To then grant a further patent for specific uses of the patented compound is to allow doubledipping, providing a far more extensive period of market exclusivity than ever envisaged by parliaments. Only in the rarest of cases should such a patent be granted - where there is a surprising result providing new knowledge or substantial net consumer benefits and where there are substantial experimentation or other costs in developing the new use.

\subsection{Requiring genuine inventiveness}

The goal of inducing technological innovation that would not otherwise take place is quite straightforward in policy (if not in political) terms. But the use of the inventive step as a proxy to ensure that the benefits should exceed the costs requires discussion. If the spillover benefits from the patented technology are high enough, then a patented invention will produce dynamic spillovers exceeding static efficiency losses. For a patent system to provide a net benefit to a nation there needs to be a strong likelihood that each granted patent provides social benefits greater than the social costs. ${ }^{15}$

If a technological limitation were combined with a high inventiveness requirement, the benefit-cost outcome of patent systems could be considerably improved. This assumes that a high inventiveness requirement is a good workable proxy for large lumpy R\&D outlays and high-speed imitation.

TRIPS requires countries to use the criteria of novelty, inventiveness and industrial application that have led to the very low inventiveness standard operating today. In many countries patents are being granted - in very large volumes - for all kinds of "inventions" that seem quite obvious in the ordinary meaning of that word. The issue of very low patent quality - a mere scintilla of inventiveness - has been well documented (by, for example, Pilch 2003; Lunney 2004; Blonder 2005; Quillen Jr. 2006; Lawson 2008; Lunney and Johnson 2012; Moir 2013c). The effect of years of lowering the definition of "inventiveness" to a set of complex legal rules has been to throw the baby out with the bathwater. Only applications which can be proved by patent examiners, on the basis of written documentation, against a lower than normal definition of "obvious", are rejected. There are estimates that some 85 percent of granted patents contain virtually no new knowledge or know-how. This comes as a surprise to many economists, who assume that the inventive step does indeed require inventiveness. ${ }^{16}$ It would also be a surprise to most law-makers. The Australian parliament was recently advised that patents, because they provide a powerful exclusive right, are granted only for things that are "a significant advance over what is known or used". ${ }^{17}$ This is simply untrue (Moir 2013c).

If the goal of patent policy is to grant patents only for those inventions which contain a benefit to the nation which exceeds the cost of the monopoly provided, then the "inventiveness" standard needs to be set to require at least a reasonable quantum of new knowledge or know-how. TRIPS allows WTO members full flexibility in defining and implementing the three traditional patentability criteria.

What happens in patent law and administration is little discussed but critical to the height of the inventive step. While the process of construing applications involves identifying what is different from existing

\footnotetext{
${ }^{15}$ Lawyers often imply - or indeed state as a fact - that it is the publication of the patent specification which constitutes the compensation to the public to offset the static efficiency losses. But if the patent specification contains no (or very little) new knowledge or know-how, then its publication is of no value and cannot offset the static efficiency loss.

${ }^{16}$ A view tellingly illustrated in a cleverly designed study which uses reported yields on patented new corn varieties as a proxy for the quantum of inventiveness. The authors were surprised that the distribution of the granted patents showed a virtually normal distribution around a mean of zero improvement (Moser et al. 2013: 3). Their surprise is evident in comments referring to discussions with examiners which confirmed to them that an invention did not have to be an improvement to be patentable.

17 Explanatory Memorandum to the Intellectual Property Laws Amendment (Raising the Bar) Bill 2011, p. 42. http://parlinfo.aph.gov.au/parllnfo/download/legislation/ems/s837 ems 561ef790-9811-43d0-b14f-04c924723c94/upload pdf/ 356916em.pdf;fileType=application\%2Fpdf. Explanatory memoranda play a critical role in interpreting statute law and are an essential component of any draft legislation presented to the Australian parliament.
} 
knowledge (prior art), subsequent steps do not involve either the question "is it inventive?" or "what new knowledge has been contributed?" Patent statutes have imported a totally different question from case law. The Australian statute and the European Patent Convention (EPC) state that a patent application is taken to be inventive unless it is shown to be obvious. ${ }^{18}$ The onus of proof therefore lies with the patent office to show that an application is not patentable, rather than with the applicant to show that a patent is merited. This presumption of inventiveness sets up the wrong question, rejecting only those applications which can be demonstrated to fail the very narrow patent obviousness test. While the normal rule of law is that words take their ordinary meanings, somehow patent law has managed to evade this rule. The patent law definition of obvious is far narrower than the normal meaning of the word. ${ }^{19}$

No amount of refinement to the question "is it obvious" will overcome the fact that it is the wrong question and is clearly ineffective in limiting patents to genuinely inventive applications (see Figure 1). Under current patent doctrines only those applications to the left of the red BB line are refused patents. But if the patent system targeted only genuine inventions, then only those applications to the right of the blue AA line would be patented. Applications lying between red BB and blue AA are the many trivial patents that are so problematic to the overall efficiency and effectiveness of patent systems. An example can assist in clarifying. Another subjective dimension is that which runs from ugly to beautiful. Determining a short-list of who is beautiful cannot be done by removing from the set only those deemed ugly.

\section{Figure 1: Distribution of inventions by current and proposed tests}

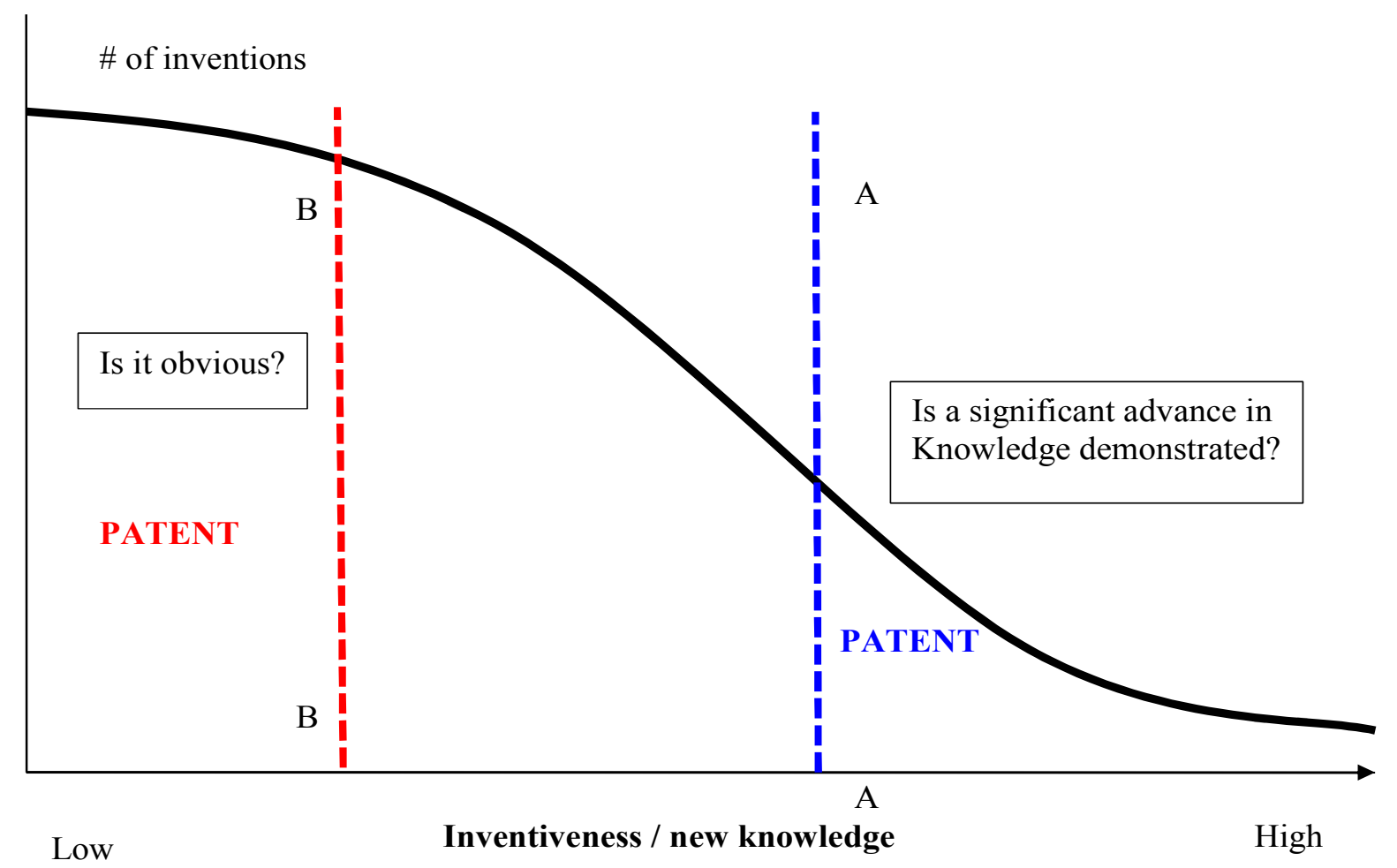

If the wrong question is currently being asked, there is no point tinkering with its myriad details, from the requirement that the inventiveness judge have no imagination, ${ }^{20}$ to the rules determining just what sub-set

\footnotetext{
${ }^{18}$ The Australian Patents Act 1990 states "For the purposes of this Act, an invention [application] is to be taken to involve an inventive step when compared with the prior art base unless the invention would have been obvious to a person skilled in the relevant art in the light of ..." Section 7(2), emphasis added. EPC Article 56 states: "An invention [application] shall be considered as involving an inventive step if, having regard to the state of the art, it is not obvious to a person skilled in the art" (emphasis added).

${ }^{19}$ Indeed an Australian Federal Court judge discounted the weight of expert evidence as the expert witnesses did not understand the patent law meaning of obvious (Welcome Real-Time SA v. Catuity Inc, [2001] FCA 445 (17 May 2001)) para 154.

${ }^{20}$ A rule overturned in the USA in 2007 (KSR v. Teleflex 127 S.Ct. 1727 (2007)) but still operating elsewhere.
} 
of existing knowledge is allowable as "prior art". These rules - established by courts rather than through careful policy design - have resulted in systems biased to the grant of uninventive patents, radically affecting the economic impact of the patent system (FTC 2003).

A parsimonious patent system would recast the test for inventiveness into a positive form. This would place the onus of proof on the applicant, who is seeking the authority of government to exercise a right to exclude others from the market. Although the quantum of inventiveness is essentially a subjective measure, it can be constrained to a greater degree of objectivity by asking "what is the new knowledge contributed?" Further, the minimum quantum required can be calibrated by explicitly recognising that the grant of a patent imposes costs on other innovating firms and on consumers. This would focus the process of examination (and any subsequent court disputes) on identifying the benefit arising from the invention, either in terms of new knowledge contributed or a contribution to net consumer surplus, such as a significant increase in health outcomes. This focus could be further emphasised by requiring examiners to make a clear statement as to why a patent grant is merited. There is a public cost associated with each patent grant and these administrative decisions should not be made without full public justification.

Countries must be free to set the inventive step at a high level. A strong inventive step requirement includes at least the following:

- Replace the dysfunctionally low "is it obvious" test with a positive test based on the questions:

$>$ "what new knowledge or social benefit is contributed?" and

> "is this benefit sufficient to outweigh the costs of reduced competition?"

- Patent statutes should not set up any presumptions as to the merits of any application. The merit must be demonstrated by the applicant.

- All exclusions from existing knowledge for patentability tests should be removed - the whole concept of "prior art" needs to be abandoned and replaced with the normal meaning of "the body of existing knowledge". It is entirely inappropriate, particularly in today's highly inventive age, to tilt the playing field against the public interest before applying tests for patentability.

- The following claims must be specified as falling below the inventiveness threshold:

$>$ new uses of known things or processes (including use in new environments)

(in particular new therapeutic treatments using known compounds); and

$>$ combinations of known elements or processes (including new forms of known things)

(unless an unexpected outcome delivers sufficient spillover benefits to outweigh the costs of reduced competition).

- Examiners should be required, in authorising a patent grant, to specify clearly the benefit which will pass to the public from the invention (either the new knowledge contributed or the substantial improvement in other outcomes such as health). Such documents should be part of the public record.

These principles do not have nice sharp unarguable boundaries. But nor does the current "not obvious" system. Further the current system has developed built-in complexity, increasing costs for business and the community alike. Over the centuries since ordinary courts have adjudicated on these matters they have systematically avoided making precise definitions of what is patentable. They have developed a number of specific tests, many of which have later been replaced as insufficiently useful. The key issue is that at the end of the day patents should be granted only when it is clear they have at least some chance of producing external benefits to offset the costs they impose on other firms and on consumers.

The proposed approach would make it harder for applicants to demonstrate the merit of many inventions. But for genuinely inventive inventions - for example for pharmaceuticals which produce a genuine improvement in efficacy - there should be no difficulty. The intent of these reforms is to eliminate trivial workshop modifications and improvements, not to stop the grant of patents for genuine inventions. This approach will clean much of the rubbish out of the system, making life simpler and easier for innovating firms. No longer will firms have to acquire large patent portfolios to swap with their competitors so they can all proceed as though the patent system does not exist. These activities simply divert resources away from productive R\&D and into non-productive regulatory activity. Where a firm (or individual) has made a 
genuine advance in technology there should be no difficulty in demonstrating the benefit and gaining the patent privilege.

What would be ideal would be to experiment with approaches along these lines. At present experimentation to ensure that the inventive step balances costs and benefits is actively discouraged, particularly by "Big Pharma" backed up by the United States Trade Representative (USTR). ${ }^{21}$ Such experimentation would be useful in developing workable practices to implement the positive "is it inventive enough?" test. It would be ideal if at least a sub-set of countries could be allowed to experiment without incurring trade sanctions. Ideally these would be either countries which have relatively small markets (for example Australia which is two per cent of the OECD market and just one per cent of the global pharmaceutical market), which do not have an embedded tradition of granting patents for every trivial variation (for example India) or countries which can start with a clean slate (new WTO members with no history of patent privileges such as Cambodia, Laos or Taiwan).

\section{$2.4 \quad$ Privileges}

\section{4.a The range of privileges}

The patent system is a very blunt instrument - providing an incentive for one party's invention by preventing commercial exploitation of the invention by other parties, even where it is independently invented. An efficient patent system will ensure that the privileges conferred by the patent are well targeted and parsimonious. Privileges that are not needed to create the R\&D incentive must be avoided because of the high risk that they will unnecessarily impede the inventive activities of others.

TRIPS spells out the privileges which must be embodied in the patent grant. The patent owner must be allowed to prevent third parties from "making, using, offering for sale, selling, or importing" the patented invention unless permission has been granted (Article 28). ${ }^{22}$ These are the privileges which were conferred well over a century ago when the local working condition was the norm in patent systems. Local working required that a patented invention be actually produced in the country. This requirement had the effect of creating pathways along which knowledge benefits could spill over to other firms and craftspeople. Generally if a patent was not worked within a period of (usually) three years, any other party could seek to use the patented invention. Over recent decades local working has come into disfavour as being an implicit form of non-tariff barrier. While there is a certain element of truth in this perspective, this would be more persuasive if the privileges granted had been re-assessed when the local working requirement was removed. With no local working requirement, there will frequently be no benefit to the patent-granting nation. The patent thus becomes a simple rent-extraction device regardless of the returns already made on the R\&D investment. It simply leads to income flows from technology-importing nations. ${ }^{23}$ In such situations it is questionable whether a patent system achieves its goal of increased R\&D investment. If this effect is sufficiently large - for example in economies where most patented inventions are imported - it can make a nation much worse off. The technology-exporting nation thus benefits from spillovers at home and rent-extraction from overseas - a kind of double-dipping.

An example illustrates. In Australia, where term extensions are regularly granted for pharmaceutical compounds, the situation can frequently arise where a compound is out of patent in an overseas economy but still in patent in Australia. Generic companies are prevented from making the product for export to the

\footnotetext{
${ }^{21}$ The US Trade Representative regularly reports on countries which do not meet US requirements on patenting, threatening these with trade sanctions. In the recent legal dispute between Novartis and the Indian Patent Office over the refusal of a patent which did not provide demonstrated improved efficacy, the USTR has made its displeasure clear and both the EU and the USA have exerted pressure on India to reduce its inventiveness standard to the current low levels applying in the USA and in Europe (R Ramachandran, "Western warnings", Frontline, 29:8 http://www.frontlineonnet.com/fl2908/stories/20120504290801800.htm ).

${ }^{22}$ Only the right to prevent import is qualified - Article 6 states that, in the context of dispute settlement, nothing in TRIPS shall be taken to address the issue of exhaustion of privileges (parallel importing).

${ }^{23}$ Australia, for example runs a negative balance on its trade in "intellectual property". IP receipts over the past decade have been of the order of $0.25 \%$ to $0.5 \%$ of the current account and payments have been two to eight times larger at $1.0 \%$ to $1.5 \%$ (IP Australia 2013: 22 sourcing data to Australian Bureau of Statistics (2012) Account 5302.0 balance of payments and international investment position).
} 
overseas market until the patent ceases in Australia. ${ }^{24}$ This situation makes generic companies operating from Australia less globally competitive than those in overseas countries where the patent has already expired. The benefit to the patent owner is small: it ensures that Australian generic companies will be delayed in their local market entry after the patent has expired. This delay - which occurs for a range of practical reasons - is effectively an unapproved extension of the already lengthy patent term.

The core of the privilege conferred on the patent owner is the privilege to prevent others from undermining the higher price that can be charged when competition is restrained. This is the action of selling in the jurisdiction where the patent has been granted.

This raises the issue of parallel importing and whether it is appropriate for governments to support business models designed to raise prices for their own consumers. Where a global company owns patents in a number of countries it is likely to set prices differentially. Such "what the market will bear" pricing models are a long way from the economists' welfare-maximising world of marginal-cost pricing. One consequence is parallel importing - where retailers act on opportunities to import officially produced goods (i.e. goods produced with the authority of the patent holder) if they can source these more cheaply. Naturally this undercuts demand for the higherpriced goods sold directly by the patent holder.

At present TRIPS leaves countries free to determine when patent (and other intellectual property) privileges are exhausted. The import of patented goods manufactured under license elsewhere does not undermine the patent privilege of sale in the market where the patent has been granted. ${ }^{25}$ But if similar goods are imported from a country where the patent has not been granted - that is they are not produced under license - their sale would contravene the granted privilege of sale in the protected market.

The net cost of patent systems was considerably increased by removing local working requirements without also streamlining the privileges granted. The preferred approach of limiting the patent privilege to sale would require an amendment to TRIPS. Developing economies - and economies with strongly negative balances on intangibles trade - would do well to flag the desire to amend Article 28 of TRIPS so that the only right granted by a patent is the right to prevent sale into the market where the patent has been granted. This more limited privilege needs to be carefully worded to make it clear that it does not limit the freedom countries have to determine when patent rights are exhausted.

\section{4.b The patent term}

Turning now to the time period of the patent privilege, it was the pharmaceutical industry that successfully lobbied both for "technological neutrality" and for a 20 year patent term in TRIPS. A major argument for the longer patent term was delays in patent processing and in regulatory approval of marketed drugs. This industry also drove the data exclusivity provisions provided in TRIPS Article 39. Once a patent has expired, other firms have the right to sell into the market from the day after the patent ceases. Perversely, preparations for sale as soon as the patent has expired appear to be unlawful in some jurisdictions, possibly due to the right to prevent manufacture. Such interpretations of patent law effectively extend the patent term. Data exclusivity provisions were introduced into the USA in 1984 following a court case where the right to prepare for immediate market entry was determined to be an infringement of the patent privileges. ${ }^{26}$ In response the US Congress passed the "Hatch-Waxman Act" (Public Law 98-417) which provides an explicit authority for generic drug companies to obtain marketing approval by demonstrating both bioequivalence to approved drugs and Good Manufacturing Practice procedures. This allows generic

\footnotetext{
${ }^{24}$ This issue was considered in depth by the 2012-13 Australian Pharmaceutical Patents Review (see Harris et al. 2013: 49-59 for a general discussion).

${ }^{25}$ As it is the patent-owning business which controls who is licensed to manufacture, any impact that parallel importing has on another market is within the control of the patent-owning firm.

${ }^{26}$ Roche Products v. Bolar Pharmaceutical, 733 F.2d 858 (Fed. Cir. 1984).
} 
companies to rely on the safety and efficacy demonstrations of the brand clinical trial data. In exchange brand companies were granted a 5-year period of data exclusivity, during which generic companies cannot use brand clinical trial data to obtain marketing approval.

It is, in fact, unethical to require unnecessary trials on human or animal subjects. International ethical standards for clinical trials forbid doctors to continue experiments on humans when there is already "conclusive proof of positive and beneficial results."27 It would therefore be unethical to ever require generic companies to undertake their own clinical trials. While brand companies pay for a large part of the cost of expensive clinical trials, they usually more than recoup these costs during the period when competition is suppressed by the underlying patent. These data are required by public health authorities for public purposes - to ensure that marketed medicines are both safe and better than a placebo. Why data provided for a public purpose can be presumed to be the commercial asset of a private company is unclear. This is particularly the case for pharmaceuticals, a notoriously secretive industry. ${ }^{28}$ Indeed it would be ideal for all such data to be placed in the public domain for use by independent medical researchers (Goldacre 2012).

Notwithstanding its success in designing the global patent system to meet its own needs, the pharmaceutical industry has succeeded in obtaining two further advantages, each based on the principle of using government powers to limit market competition. Despite the technological neutrality provisions of TRIPS, the USA has sought and gained, through FTAs, the right of a patent term extension of up to 5 years for pharmaceutical products where there have been delays in achieving regulatory approval for market entry. The very generalised terms of TRIPS Article 39 have since been solidified and extended through trade agreements. Data exclusivity provisions give pharmaceutical companies far stronger, and cheaper, market monopolies than do patents. Indeed it is arguable that this is a form of double-dipping and that a patentprotected drug should not also be able to claim data exclusivity.

Patent privileges should be provided only where they are needed to induce an invention. Following this principle, term extensions should be provided only where the patent owner provides financial data to government showing that a risk-adjusted return on the R\&D investment has not yet been achieved. Similarly, data exclusivity provisions should be conditional on proof that a commercial return on the R\&D outlay has not yet been achieved.

\subsection{Incentives, penalties and strategic gaming}

The essence of patent policy is the incentive to change investment behaviour. Because of this the normal rules of law (for criminal behaviour or contracts over physical property) will not always deliver good outcomes. In economics the dangers of regulatory intervention in markets are well-known and so clear evidence of a net increase in welfare is required to justify the intervention. In addition the cost of the intervention must be less than that of any alternative means of achieving the goals. If these two criteria cannot be achieved, then a country will be worse off for adopting the intervention. "Clear evidence" aligns with the legal standard "beyond reasonable doubt." Lawyers are reluctant to use this standard outside criminal law. But a granted patent provides a powerful exclusive right that can impact strongly on firms which have not been a party to the decision to grant a monopoly. The patent privilege is the right to prevent others from commercially exploiting a particular area of technology. ${ }^{29} \mathrm{~A}$ very high standard of proof is therefore indicated.

\footnotetext{
${ }^{27}$ World Medical Association, Declaration of Helsinki: Ethical Principles for Medical Research Involving Human Subjects, $18^{\text {th }}$ World Medical Association General Assembly, Art. 20, http://www.wma.net/en/30publications/10policies/b3/17c.pdf. Given that Article 20 prevents the continuation of trials when conclusive results are known, one can presume that it is also unethical to commence such trials when there are already conclusive results.

${ }^{28}$ And one which does not hold back from providing completely unrealistic estimates of costs, even after such estimates have been shown to be inaccurate (see Light and Warburton 2011). The pharmaceutical industry has never tabled data showing they are unable to achieve a risk-adjusted return on their R\&D investments without these term extensions.

${ }^{29}$ As Quillen has said, for an established firm the critical issue for proceeding with an innovation is the soundness of the innovation and whether it is impeded by others' patents, not whether you own patents on it (Quillen Jr. 2008: 61).
} 


\section{5.a Incentives to maintain patent standards}

A range of incentives and disincentives are embedded in the patent system. These are rarely discussed. There is a major asymmetry in the incentive to challenge an invalidly granted patent compared to the incentive to sue for infringement. If a patent-holder sues for infringement and wins $s /$ he gains all the consequent benefits (damages, costs, payment of license fees and a greater ease in obtaining license fees from other parties). Where an innovating firm finds their business path blocked by a seemingly invalid patent, s/he would bear all the costs and risks of legal action yet instantly share all the benefits of revocation (clearer market access) with all other companies competing in that field. There is one exception. The US Hatch-Waxman Act provides an incentive to companies which successfully challenge an invalid pharmaceutical patent - they gain a period of 180 days of market exclusivity for their generic version. ${ }^{30}$ In the very large US market this potential reward substantially exceeds the cost of legal proceedings.

In other technology fields, and in other jurisdictions, this asymmetry in incentives removes any incentive for those negatively affected by patents to help to maintain standards - most weak patents are never challenged. In some jurisdictions an alternative strategy has been developed which is effective in helping to remove invalid patents from the system - pre-grant opposition. As the European Patent Office (EPO) experience shows, when such low-cost procedures are well designed, they are actively used (see, for example, Wagner 2008). Pre-grant opposition is infrequently used in the USA where there are major weaknesses in system design - anyone using pregrant opposition loses rights in subsequent court actions.

Another perverse incentive is that a firm whose patent is found to be invalid has to recompense only the other party to the legal dispute. The many other firms also negatively affected by the invalid patent would each have to go to court to seek compensation. That is, there is no general procedure for firms with invalidated patents to repay in full the unjustified profits they have made. This is not only inefficient and unfair but also encourages firms to seek many dubious patents - the profits from these far exceed any costs if a patent is found invalid. As the recent example of the patents over BRACA1 and BRACA2 genes shows, patents can be used for most of their market life before they are found fully or partially invalid. In contrast, where a firm is found to infringe a valid patent, one form of compensation is the payment of all profits derived from this infringement. These clearly asymmetrical penalty structures lead to a situation that actively encourages firms to seek patents for trivial inventions. Indeed the strategy of legally defending very low quality pharmaceutical patents is actively recommended to pharmaceutical firms as the profits from the additional time in the market during protracted legal wrangling will far exceed the legal costs. ${ }^{31}$

Little consideration appears to have been given to the role of these perverse incentives in undermining the objective of patent policy. There are "fair basis" rules that limit unfair use of divisionals and amendments, and in the USA there are penalties for deliberately misleading the patent office. But there are no other penalties for profiting from an invalidly granted patent, although this can substantially harm many consumers as well as other innovative firms. Nor are there penalties for undermining the system itself and substituting semantics for technology, pretending software is not software, or pretending that discoveries can be classed as inventions (e.g. DNA). Indeed in some jurisdictions applicants appear to be able to amend patent claims endlessly, seeking for a form of words that will gain the approval of the examiner.

Endless amendment ${ }^{32}$ combines with the lack of any means of recouping profits from invalid patents to create a form of moral hazard - strong incentives to seek patents for "inventions" that fall far short of

\footnotetext{
${ }^{30}$ This privilege is limited to the first generic entrant (see Holovac 2004).

31 "... for a successful product, the benefit of even a short time of additional proprietary sales may easily outweigh the costs of patent litigation" (Burdon and Sloper 2003: 238).

${ }^{32}$ In some jurisdictions, such as the EPO, there are limits to how frequently specifications can be amended. But in jurisdictions such as the USA and Australia there seem to be no effective limits and applications can go through six or more amendments to the claims.
} 
delivering any benefit. Firms successfully challenging a patent will be awarded damages, but as noted above other parties have no cheap or simple avenue to seek compensation. ${ }^{33}$

In Australia the right to amend a patent claim was introduced in 1953 and this policy change has never been evaluated. My study of the doctrines leading to the grant of patents for "inventions" which contribute no new knowledge indicates that many of these would never be granted if the right of amendment were limited (Moir 2013b). Where there is an error that might prejudice grant to an otherwise inventive application, a single right to amendment could be allowed in special circumstances. Apart from this single instance, any further amendments should not be allowed.

There is also considerable "doctrinal incoherence" (silly outcomes) in the patent system. Thambisetty notes a UK case where the failed challenger of a patent's validity had to pay damages for infringement even after the patent had been revoked after a successful subsequent challenge. ${ }^{34}$ This is economic policy gone mad.

When tax is erroneously under-estimated there are well-established mechanisms for repayment (including with penalties depending on the circumstances). When social security payments are made in error, these are recouped. Providing a parallel mechanism for ensuring that patent-holders do not benefit from unjustified monopolies would substantially change the incentive for firms to seek more and more patents for trivial "inventions".

A low inventive step encourages Type II errors - grant of a patent for an application which would happen anyway or where there are insufficient spillover benefits to offset costs (a "bad" application). In contrast a high inventive step risks Type I errors - rejection of "desirable" applications (those contributing new knowledge from which other firms and inventors can benefit) (Jensen and Webster 2004). A closely related issue is who bears the cost of correcting administrative errors?

All jurisdictions provide substantial opportunities for rejected patent applicants to challenge an unfavourable decision. With Type I errors it is the party seeking the monopoly privilege who bears all costs and risks of seeking a second opinion and who will gain the full return if successful. In contrast, where the inventive step is low and Type II errors are more likely, it is innocent third parties who bear the costs of dealing with incorrect decisions. As noted above there is very little incentive for such corrections.

This situation could be radically changed if patent holders were required to repay all profits ever earned from any invalid patent. After reimbursing the challenging firm for legal and other costs in the challenge, the balance could be shared between the challenging firm, other firms in the market who had suffered damage from the invalid patent and agencies representing competition and consumer interests. It is, after all, consumers and competitors who bear the costs of the patent system.

Introduce clear mechanisms for
patent holders to repay all profits
made from products underpinned by
patents which are subsequently
found invalid. Share these repaid
profits between the successful
challenger and consumer and
competition advocacy bodies.

Outside of pharmaceutical patents, the incentive to challenge bad patents has been particularly low in the USA where granted patents have a presumption of validity (Jaffe and Lerner 2004). This adds substantially to the costs and risks of a third party challenger.

\footnotetext{
${ }^{33}$ In Australia, for example, a secondary pharmaceutical patent over clopidogrel delayed generic entry by 3 years. A 5-year term extension on the patent was simultaneously invalidated. It has been estimated that the total cost to the Australian taxpayer of use of this invalid patent was some \$A644 million (Alphapharm submission to the Australian Government's Pharmaceutical Patents Review, p.6. Unfortunately IPAustralia has removed all submissions from the website on the pharmaceutical patents review. Copies can be obtained from the author). There are no mechanisms for the government to seek repayment of this unjustified subsidy beyond the $\$ A 60$ million accruing during the injunction period (Moir and Palombi 2013: 25).

${ }^{34}$ Coflexip v Stolt Comex [2004] FSR 7 (Ch (Pat Ct)) and [2004] FSR 34 (CA) see Thambisetty 2009: 23.
} 
Patent statutes must make it clear that no granted patent can be presumed valid. Action should be taken to educate judges who ignore statutory law.
The Australian patent statute expressly states that there is no presumption of validity in the fact that a patent has been granted. ${ }^{35}$ Despite this a Federal Court judge has recently qualified this express disclaimer stating that "[r]egistration of the patent is, of itself, prima facie evidence of validity." ${ }^{36}$ Again this indicates that (some) judges have little hesitation in changing the law, regardless of the express wording of the statute. As Quillen noted in relation to judicially determined extensions to patentable subject matter in the USA such judicial policy-making occurs "without any inquiry into the facts" or the public policy implications (Quillen Jr. 2008: 71). When policy is made in this manner it is no wonder it creates unbalanced, suboptimal, outcomes.

There is no such legal presumption about a claim to infringement in the USA. This means that the standard of proof required for the alleged infringing party is higher ("clear and convincing evidence") than it is for the patent-holder ("preponderance of the evidence"). ${ }^{37}$ History shows that patent offices tend to grant many patents which courts subsequently find invalid. Quillen (2006) reports on a 1980 study - prior to the creation of the pro-patent Court of Appeals for the Federal Circuit (CAFC) - by Koenig (1980) which calculated that US appeal courts found nearly two-thirds of patents challenged for validity were in fact invalid. This is an extremely high error rate. Patent offices work closely with those who seek patents and those who assist would-be patent-holders. But they have little contact with innovating firms which are harmed by the grant of invalid patents. These factors probably underlie problematic outcomes such as "Swiss medical claims" where the Swiss Patent Office designed a set of words which could be used to undermine the clear intent of the EPC (see below).

\section{5.b Penalties for infringement}

Penalties for infringement are well developed in patent systems. The tension between the economic goal of disseminating new knowledge and technology and the competitive restraint provided by a patent traditionally meant that the usual penalty for infringement was payment of royalties. This simultaneously ensured a proper incentive for the inventor and the more widespread use of the technology.

In the USA there has been a tendency to issue injunctions as a remedy for patent infringement since the precedent-setting penalties in the 1986 Kodak-Polaroid case. From an economic policy perspective this seems disproportionate - injunctions involve an extremely high cost to many innocent parties, particularly those who lose their jobs. Similarly, since the Texas Instruments case in 1985-86 extraordinarily high levels of damages have been awarded in the USA. ${ }^{38}$ Again it is hard to see how excessively high levels of damages achieve anything other than encouragement to abuse the patent system. In 2006 the Supreme Court acted to stop the use of injunctions except in exceptional circumstances. ${ }^{39}$ This experience, and the lengthy delay between the CAFC adopting a policy of regularly using injunctions and the Supreme Court acting to constrain the use of injunctions, points to the need for clear specification of appropriate remedies for infringement in patent statutes.

\footnotetext{
35 "Nothing done under this Act or the PCT guarantees the granting of a patent, or that a patent is valid, in Australia or anywhere else." Patents Act 1990, Section 20(1).

${ }^{36}$ Novartis v Hospira [2012] FCA 1055 per Yates J, paras 51, 91-94.

${ }^{37}$ Jaffe and Lerner 2004: 108-109.

${ }^{38}$ For a discussion of the impact of this and the Kodak-Polaroid case on the salience of patents in the US business world see Hall and Ziedonis 2001.

${ }^{39}$ US Supreme Court, eBay Inc. v. MercExchange, L.L.C., 547 U.S. 388 (2006).
} 
Patent policy is clearly civil law, implementing economic policy. Any action which undermines the granted rights can cause an economic loss to the privilege-holder - a matter pursued through civil courts. The introduction of criminal penalties into copyright law was an accident of history. ${ }^{40}$ Unfortunately it has spread globally and patent privilege-holders are now seeking its extension to trade secrets. ${ }^{41}$ There is no sound reason for this. There has already been a massive upset to the normal rule of law in TRIPS Article 34 where the "innocent until proven guilty" standard no longer applies in respect of process patents. Because of the damage patents can cause to other innovating firms, it is important that infringement penalties be as parsimonious as the privileges granted. They need to be focused on compensation for the lost earnings that constitute the patent incentive. They must avoid damage to innocent third parties (such as employees). Nor should patent policy ever been seen as criminal law.
Patent law is civil law and all penalties should be civil. As the damage done by infringement is hurt of profits, the only proportionate penalties are ameliorating this hurt. Patent infringement penalties should, to the maximum extent possible, avoid doing harm to innocent parties.

Normal rules should apply, with alleged infringers assumed innocent until proven guilty.

\section{5.c Strategic games playing: semantics}

The lack of clearly thought through incentives and disincentives in the patent system combines with the (possibly deliberate) lack of policy-oriented data to ensure substantial strategic games playing. Such games range from the deliberate flouting of patent statutes (for example "Swiss medical claims") through evergreening to frequent but low-level games where semantic inventiveness replaces technological inventiveness.

When one starts studying the patent system one of the first striking aspects is its peculiarly archaic language. "Art" is used to mean technology, though "prior art" means allowable existing knowledge. If judges used modern language - such as technology for technology - might they have been more circumspect in extending patent privileges to fields such as business methods? Certainly business is an art, but it is not a technology in any normal sense of the word.

All patent terminology should be modern language and all words should take their ordinary meanings.

Members of the patent community strongly resist attempts to modernise the language. It appears that continued use of archaic language is integral to the complexity which prevents outsiders from enquiring too closely into the costs and benefits of the patent system. For example using the phrase "prior art" for "allowable existing knowledge" hides the limits placed on existing knowledge before the novelty and inventiveness tests are applied.

While semantic problems bedevil rules and procedures, arguments about shades of meaning in words are also frequently found during the examination process. Such complaints are not new, but remain unaddressed. Edwards, for example, comments that: "[a]s it reaches the patent office the application combines technological and legal invention, and the latter, if of superior quality, may do much to offset deficiencies in the former" (Edwards 1949: 218). My own empirical work has focused on business method patents, which not being a technology might be more subject to such linguistic arguments. Nonetheless the examples found there are startling. In three out of four cases where the European Patent Office (EPO) granted a patent for the proposed business "invention" the application was initially rejected as not technically inventive. But when specific words were moved from dependent to independent claims suddenly a patent was granted (Moir 2013a). Unfortunately EPO examiners do not have to give any reason for grant of a patent, so one cannot interrogate the underlying thinking. Certainly from a policy viewpoint there can be no benefit to the public in the grant of a patent where "inventiveness" is based on narrow

\footnotetext{
${ }^{40}$ See Boldrin and Levine (2008, chapter 2, pp32-33) for an account of the disruptions caused by private actions to enforce new copyright privileges in respect of sheet music. This led to a new copyright law in 1902 which for the first time made copyright violation a criminal offence.

${ }^{41}$ See Article H.8 of the TPPA leaked IP chapter (available at https://www.wikileaks.org/tpp-ip2/\#article e4.
} 
shades of linguistic meaning, or which claim specific words are in, rather than genuine technological invention.

Some types of semantic inventiveness are used at a strategic level and have system-wide impacts. For example the EPC limits the patentability of methods of medical treatment. But the EPO grant patents for the first medical use of a known substance. This seems at odds with the wording of Article 53:

"European patents shall not be granted in respect of: ...

(c) methods for treatment of the human or animal body by surgery or therapy and diagnostic methods practised on the human or animal body; this provision shall not apply to products, in particular substances or compositions, for use in any of these methods."

Clearly Article 53 allows pharmaceutical products, for use in such treatments, to be patented. Given that the product patent covers all commercial uses, further patents for methods of using the product seems to reward the inventor twice. Quite how the EPO came to interpret these words as allowing patents for particular uses of patentable pharmaceutical products is unclear. Setting aside this conundrum about patents for first medical uses of patented compounds, Thambisetty indicates that "as a response to pressure from the pharmaceutical industry the EPO was interested in extending patent product protection to second medical use of known products" (Thambisetty 2009: 17, emphasis added). She provides an example of the minor variation in wording designed by the Swiss Patent Office to overcome this exclusion (a technique known as "Swiss medical claims"). This comes very close to those who are supposed to uphold the law taking action to undermine it. It is possible largely because the patent system's deliberate complexity hides it from proper accountability.

Some of the decisions of the quasi courts of the EPO (the Technical Boards of Appeal) involve at least substantial mental gymnastics - though some consider the EPO "outright violates the European Patent Convention" (Bakels 2012: 2). Such semantic games have been roundly criticised by UK courts. In the most strongly worded of these admonitions, Prescott J stated that "[y]ou are not allowed to get round the objection - that you are attempting to patent a computer program - by claiming it as a physical artefact, a mere change of form." ${ }^{42}$

Stepping back from the patent system one is reminded of the "creative accounting" of the late 1970s and early 1980s that allowed payment of tax liabilities to be discretionary for many of those with highly trained tax lawyers. The public revulsion over the existence of choice in the payment of tax led to a substantial degree of reform with overarching principles trumping specific rules. Thus "antiavoidance" principles deem specific financial arrangements void for tax purposes if their principle purpose is to avoid payment of tax. The semantic games in the patenting industry seem designed to obtain patent monopolies for trivial "inventions". They could be addressed with similar approaches. ${ }^{43}$

Anti-avoidance principles developed to reduce taxation liabilities should be investigated and adapted for use in patent systems. In particular the technique where over-arching principles trump specific rules should be developed to remove semantics as a basis for patent grant.

\subsection{Transparency, evaluation and audit}

One reason economists are so reluctant to endorse regulatory interventions in markets is that such interventions create the opportunity to benefit financially from how the rules are shaped. This encourages beneficiaries to lobby to change the rules even further in their favour. Adding insult to injury, the costs of this lobbying are tax deductible. Classes of agents arise to argue which side of the regulatory boundary their client should be on. ${ }^{44}$ These agents also develop vested interests. In the USA they persuaded Congress to drop a proposal to investigate the real-world impact of granting patents for business methods. ${ }^{45}$ Such

\footnotetext{
42 In the matter of Patent Applications GB 0226884.3 and 0419317.3 by CFPH L.L.C, [2005] EWHC 1589 (Pat) at 36.

${ }^{43}$ Important rules for preventing abuse of complex systems where there are substantial pecuniary awards from undermining the system are discussed by Braithwaite (2005: 144-155).

${ }^{44}$ Free trade has decimated the old tariff consultant profession. But there has been a massive increase in the number of patent attorneys (Barton 2000).

${ }^{45}$ The American patent bar lobbied successfully to prevent the US Government Accountability Office (a highly respected research
} 
regulatory capture creates a vicious cycle favouring sectional interests rather than the public good. The patent system is an excellent example of this.

There is no tradition of proper oversight of the activities of patent offices from a competition perspective. Patent offices are usually located in industry portfolios making them particularly susceptibility to regulatory capture. Formal statements from patent offices suggest they do not see consumers or non-patenting innovators among their "stakeholders". Several well-informed students of the patent system suggest that patent offices have become part of an in-grown self-reinforcing community impervious to (and generally unaware of) the evidence as to possible negative impacts from the current "strong" ${ }^{46}$ system (Thambisetty 2009; Drahos 2010). ${ }^{47}$ To offset these continuing pressures patent systems need clear built-in systems for effective oversight, including audit and evaluation, and mechanisms to draw them into wider policy circles.

\section{6.a Collect data on the impact of patents}

An entirely unacceptable aspect of patent systems, given that they have been a tool of economic policy for several hundred years, is the lack of data on patent use and patent costs for use in improving the design of patent policy. There have been recommendations to collect such data but these have rarely been implemented. ${ }^{48}$ Indeed there are suggestions that well-organised beneficiaries of an increasingly broad patent system have actively undermined such proposals. ${ }^{49}$ It seems quite extraordinary that governments hand out thousands of monopolies yet collect no data on their use. ${ }^{50}$

Little of the reams of data on patent applications provided by patent offices is useful for policy purposes. None give any insight into how the granted monopolies are used. ${ }^{51}$ It would be a very simple administrative procedure - virtually tick-a-box - to require at least some data on use as patents are renewed. While this might be onerous for companies who own many thousands of patents, ${ }^{52}$ if the system is to be based on evidence rather than myth, then such data are essential. An alternative which would be cheaper for frequent patenters, though it might disclose more information, would be to require advance advice to the patent office before any legal action

Patent Offices should require simple data on how patents are being used as a condition of renewal. This should include data on any formal use of the patent in legal proceedings (including solicitor's letters). was taken to enforce a patent.

body) from undertaking a study of business method patenting. This had been part of the penultimate draft of the American Inventors Protection Act 1999 but was removed in the final statute (Kahin 2003).

46 "Strong" in this context means strong rights for patent-holders and very weak protection for consumers and competitors.

${ }^{47}$ A telling example of the isolation of the patent community, even from the world of industrial innovation, is the 2008 Australian National Innovation System (NIS) review (Cutler et al. 2008). Simultaneously IP Australia's advisory body was charged with reviewing what subject matter should be patentable (ACIP 2008). Although IP Australia is part of the Department of Industry and Innovation, responsible for the NIS review, members of the NIS review team were unaware of the ACIP review and the ACIP review team was ignorant of the NIS review - until I took action to cross-inform them.

${ }^{48}$ For example collection of use data at the time of patent renewal was recommended in 1984 in Australia (IPAC 1984: 10). This recommendation has never been implemented. Yet in his speech at the first Pacific Rim Innovation Conference (January 2010), the Director General of IP Australia went on the public record regretting the lack of data on patent use.

${ }^{49}$ Bessen and Meurer (2008, p.293-4) comment that the Federal Trade Commission (FTC) recommendation most prominently rejected by the Intellectual Property Owners Association (dominated by patent lawyers from large firms) was recommendation 10 "expand consideration of economic learning and competition policy concerns in patent law decisionmaking." See also footnote 45.

${ }^{50}$ And never have, except for a brief period in Canada following the Firestone (1971) review.

${ }^{51}$ Indeed in Europe (certainly using the UK and EPO search systems) it is not possible for an innovator to search a particular technology area (whether by technology class or keywords) and obtain a list of all patents currently valid in that country. The esp@cenet database will not return more than 500 entries and does not allow searching by grant status. The European Patent Register will return all hits, but also does not allow limitation by grant status - each returned case has to be searched individually by legal status to find which have been granted and are in force. This seems an extraordinary abrogation of the implicit duty of patent offices to provide public information about the patents they grant.

${ }^{52}$ IBM, for example has acquired more than 67,000 patents in the last 20 years (Frier 2013). However about half these have ceased and many of the remainder are simply the same "invention" patented in a number of countries. A relatively small number of companies own a relatively large proportion of all granted patents. The 300 most frequent patenting companies owned 45 percent of patent grants in the period 1990 to 2001 in each of Australia and the USA - on average 206 patents in Australia and 2190 in the USA (calculated from Moir 2008: Table 2). 
Despite the lack of policy-relevant data from the patent system, there are substantial data from surveys of industrial innovation and these throw considerable light on the role and importance (or lack therefore) of the patent system. These are well reviewed elsewhere (López 2009). What is surprising is that National Innovation Surveys do not build on the work of the Yale and Carnegie-Mellon surveys. One critically important omission is data on how innovating firms are affected by the patents that other people own. The issues of blocking and hold-up patents are widely understood to be important policy questions. Yet we collect no data. ${ }^{53}$ Another important omission is data on the cost of copying. Mansfield and colleagues (1981) did the initial empirical work on this issue and it was replicated in the Yale survey (Levin et al. 1987). Since then there has been no new empirical work despite the importance of the cost and speed of copying as a motivating factor for the patent intervention. This is unfortunate as new technologies (such as computer-aided manufacture, computer-aided design and 3-D printing) and new economic players (China, India) may have changed the time and price of copying.

\begin{abstract}
Develop new questions for National Innovation Surveys to directly address issues relevant to the role of patents in promoting technological innovation. In particular address issues of technological hold-up or diversion, the costs of defensive patenting and the speed and cost of imitation.
\end{abstract}

\section{6.b Regular audit and periodic evaluation}

The patent system seems to have had a remarkable ability to escape review, evaluation or audit since the US Senate enquiry of 1958 (Machlup 1958). This is despite the trend towards greater evaluation of government programs across all beneficiary groups. One reason for this is that it is not a budget-funded (outlays) program. Like tariff barriers, the costs are distributed across the economy. But unlike tariffs, the costs are not readily amenable to quantification, and relevant data are difficult to obtain. There are, however, three empirical studies of the welfare effect of pharmaceutical product patents (Chaudhuri et al. 2006; Branstetter et al. 2011; Dutta 2011). All show that the consumer surplus effect is six to eight times greater than the producer surplus effect, indicating a substantial net welfare loss from the reduction in competition caused by product patents. These results suggest that a straightforward subsidy to pharmaceutical companies would be more efficient than the provision of patents.

The development from the mid-1980s of a "stakeholder" culture was intended to increase the sensitivity and responsiveness of government agencies to the groups affected by their actions. Unfortunately for the patent system, this reform has simply embedded regulatory capture, with revolving doors between patent offices, patent attorney firms and frequent users of the patent system. Opening up this inward-looking culture could readily be achieved by moving patent offices from industry or legal portfolios to agencies charged with promoting competition. This would broaden the "stakeholder" definition to include, at a minimum, consumer interests and competitive voices (for example the generics medicine industry).

In countries new to patenting, where the bulk of the applications are for pharmaceutical products or processes, relevant competition and public interest issues will most likely be handled by the health ministry. In such situations the objectives of ensuring balance between the incentive and competition elements of patent systems might best be achieved by locating patent offices in the ministry of health.

Locate patent offices in departments which are responsible for maintaining competition in the economy or considering public impact aspects granted patents.

Regular economic evaluation would further strengthen a more balanced approach to the grant of patent privileges. This would need to be undertaken by economists independent of the patent system and its beneficiaries. Organisations such as the US Government Accountability Office (GAO) are precisely the kind of independent bodies that should be charged with such evaluations. It was however precisely this independence - phrased as "they are not properly qualified" - which led to the American patent bar

\footnotetext{
${ }^{53}$ Though the recent European Commission study into the pharmaceutical industry places some rather large numbers on the losses to taxpayers of the strategic games that "Big Pharma" plays with regulatory bodies, including patent offices (European Commission 2009).
} 
lobbying to prevent the GAO from being mandated to undertake a study of business method patenting. ${ }^{54}$ Any attempt to set up an independent evaluation of any part of the patent system immediately leads to cries of lack of representativeness. For example the Australian Federation of Intellectual Property Attorneys of Australia (FICPI) took issue with the composition of the independent panel established to review the pharmaceutical patent system in Australia in late 2012, as "there is no representative on the panel who is representative of the interests of the innovation based pharmaceutical industry. ${ }^{155}$ Effectively they were objecting to the independence of the panel. When determining regulatory policy a fundamental issue is that "one must look further afield than those involved in and regulating an industry when canvassing opinions regarding changes in public policy" (Beggs 1981: 44). It is precisely this requirement for independence that the "stakeholder" groups do not understand.

There is a place for sectional interests to lobby elected governments, but it should not extend to preventing the independent review and evaluation that creates the foundation for sound public policy debate.

As well as regular evaluation there should also be a system for independently auditing the inventiveness standard being implemented by the patent office. As discussed above the incentives to ensure independent review of possibly erroneous decisions are weak. Further, in at least some countries, judges have shown themselves to be poor defendants of the public interest in patent systems. Periodic independent review of applications in specific fields (including both grants and borderline rejections) by experts would do much to ensure that the new higher standards were maintained.

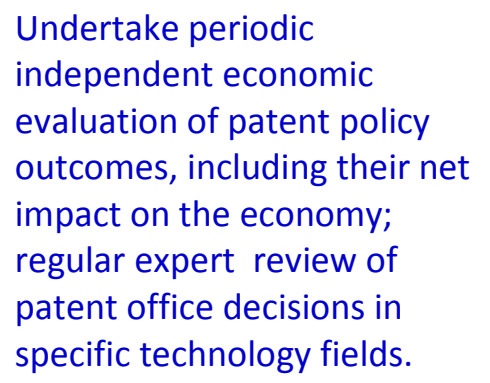

\section{Comparison with TRIPS and with USTR demands}

Having defined the key elements of a balanced patent system it is useful to see how this compares both with TRIPS and with the aggressive patent policy demands being put forward by the USTR. With few exceptions the US ask has increasingly favoured patent owners, particularly pharmaceutical companies. The US ask in the leaked IP chapter from the TPPA round ${ }^{56}$ is compared to a balanced system. The current text is quite complex, and there is still substantial disagreement between the parties to the negotiation as to the content of this chapter. ${ }^{57}$

The items identified as essential to a balanced patent system are useful in developing a schema to manage analysis of this complex text. This also allows different treaties, or proposed texts, to be set out in a comparative tabular form (see Table 1).

\subsection{Objectives}

TRIPS has perhaps the best objective statement of any legal document governing the grant of patent privileges. Although TRIPS covers a range of "intellectual property" interventions, Article 7 seems to be drafted specifically for patents. It both specifies that the subject matter of patents is technology and calls for balance between the interests of creators and users of new technology.

Studies of a range of legal decisions on patents demonstrate clearly that judges have little understanding of the goals of this economic policy. Better guidance to judges, in the form of clearly stated objectives, could pay substantial dividends. There is no US proposal for IP objectives for the TPPA, though there are proposals from other negotiating parties.

\footnotetext{
${ }_{55}^{54}$ Personal conversation with a senior representative of the American patent bar, March 2011. See footnote 45.

${ }^{55} \mathrm{pp}$ 1-2. As IPAustralia has dismantled this website a copy can be obtained from the author.

${ }^{56}$ This updated version of the paper is based on the leaked 16 May 2014 text (https://www.wikileaks.org/tpp-ip2/). As presented to the ISS conference it was based on the leaked 13 November 2013 text (https://wikileaks.org/tpp/). Table 1 footnotes any differences between the 2014 and 2013 versions.

${ }^{57}$ As, indeed there was to the 2011 and 2013 versions. The general, copyright and patent elements of the 2011 version, together with disagreements between the parties, are fully discussed in Flynn et al. 2012. There have been only a few changes between the 2011, 2013 and 2014 texts, at least with respect to the US patent ask.
} 


\subsection{Patentable subject matter}

Patentable subject matter is not specifically discussed in TRIPS - basically patents are to be granted for inventions "in any field of technology". But some technological inventions can be deemed unpatentable those that contravene the ordre public; plants, animals and biological processes for their production (but not microorganisms); and diagnostic, therapeutic and surgical methods. Implicitly software can be excluded as Article 10 specifically requires that copyright privileges be provided for software.

In the TPPA the US is seeking to narrow exceptions to patentable subject matter. TRIPS allows nations to refuse to grant patents for plants and animals other than micro-organisms. ${ }^{58}$ Draft TPPA Article E.1.3 ${ }^{59}$ requires the grant of patents for plants and animals. ${ }^{60}$ TRIPS allows nations to refuse to grant patents for diagnostic, therapeutic and surgical methods. The 2013 draft TPPA had included a US proposal to allow patents for diagnostic, therapeutic and surgical methods "if they cover a method of using a machine, manufacture, or composition of matter (Article E.1.3(b)). This inclusion was opposed by 11 of the 12 negotiating parties and has been dropped from the $2014 \mathrm{draft}$. The $2014 \mathrm{draft}$ includes a proposal from 10 of the negotiating parties to specifically allow exclusion from patentability for diagnostic, therapeutic and surgical methods. The text does not indicate that the other three nations - the USA, Japan and Singapore have formally opposed this.

\subsection{Inventiveness}

Patent systems can be re-designed to use an inventiveness test set to ensure each granted application would deliver a net benefit to the world if not to the nation. ${ }^{61}$ TRIPS is largely silent on this matter, allowing signatories full flexibility in designing patentability standards. TRIPS does however constrain WTO members to grant patents on the basis of the discredited criteria of novelty, inventiveness and utility. Few countries have taken the opportunity of this freedom to set patentability criteria at levels that achieve the TRIPS objective of "the mutual advantage of producers and users of technological knowledge" (Article 7). The major example of a country that has tried to do this is India, which drew on the European Medicines Agency's procedures in Section 3(d) of the 2005 Patent Act. ${ }^{62}$ When this was implemented with respect to a single patent application, both the USA and the EU made strong representations that such a high standard for grant was unfair and constituted "free riding".

Given this response to India's use of TRIPS flexibilities, it is not surprising that in the TPPA the US seeks to constrain all parties to the exact procedures it has used to create the very low inventive step in the USA. This constraint is hidden in a footnote that requires inventiveness to be determined on the basis of whether it "would have been obvious to a person skilled or having ordinary skill in the art having regard to the prior art." (footnote to Article E.1). Further the USA is seeking to impose its very low standards on its trading partners by specifically requiring that patents be granted for any new uses and methods of using known products - effectively eliminating any inventiveness requirement. Although India is not a party to these negotiations, the specific language of Article (E.1.2) is clearly directed at undermining Section 3(d) of the Indian Patent Act. The extraordinarily low standard that the US proposes would encourage rent-seeking and a shift of resources into the process of patenting rather than into genuine innovation. It would make it impossible for countries where the majority of patents are owned by foreign entities to design a system that would balance the interests of producers and users or technology, thus contravening TRIPS Article 7.

\footnotetext{
${ }^{58}$ TRIPS Article 27.2 also allows the exclusion of "essentially biological processes for the production of plants or animals other than non-biological and microbiological processes, though it does require "protection" for plant varieties.

${ }^{59}$ Each article in the leaked 2013 and 2014 versions of the IP chapter is preceded by the letters QQ. These standard letters are not included here.

${ }^{60}$ Australia already agreed to provide patentability for plants and animals in the Australia US Free trade Agreement (AUSFTA) which came into effect in 2005 (the exclusion is absent from the list of allowed exclusions in Article 17.9.2).

${ }^{61}$ To the world as where patented goods are imported there is little benefit to the granting nation.

${ }^{62}$ This section is also drafted as a limitation to patentable subject matter rather than the required degree of inventiveness (though it could be interpreted as signaling that such minor variations do not meet the definition of an invention). For a discussion of the use of subject matter or inventiveness criteria to limit patentability see Thambisetty 2014.
} 


\subsection{Privileges}

TRIPS conferred extremely broad privileges on patent owners, though also provided some limited exclusions to these privileges. The US ask in the TPPA would limit exclusions from the broad range of patent privileges solely to the use of data in patents for regulatory approvals. The US opposes provisions to allow manufacture for export to countries where the patent is not in force. However US opposition to the overall provision that the TPPA shall encourage international exhaustion of rights (thus allowing parallel importing) has been withdrawn in the 2014 version. ${ }^{63}$ The US is also seeking to exclude anti-competitive conduct as a reason for revocation of a patent (Article E.3).

Not satisfied with the TRIPS extension of all patents to 20 years to allow for processing delays, the USA is now seeking further patent term extensions if patent processing is delayed beyond specified limits. ${ }^{64}$ These might rarely come into force as most patent processing delays are due to applicants taking the maximum allowable time to submit each response to a negative examiner's report. Nonetheless where there is an administrative oversight, this is a high price for the public to pay for any such administrative error. Any such requirement should be conditional on the applicant advising the patent office some (specified) months before the final date on which the examiner's report is due.

Term extensions due to marketing authority regulatory delays have been sought and gained by the USA in many FTAs, and are again included in the proposed TPPA. As for AUSFTA, the draft text (Addendum I, Article E.14) is very broadly worded. Countries are allowed to place conditions and limitations on the implementation of this policy. This drafting would allow countries to require evidence that a return on R\&D investment had not yet been achieved, before granting any such term extension.

Provisions for data exclusivity were included in TRIPS, but in the most general terms (Article 39.3). In most countries the timely entry of generic competitors as soon as a patent expired would be seen as good public policy. There would rarely be occasion to find that use of expensive undisclosed data had been on commercially unfair terms. Indeed requiring generic companies to undertake new clinical trials where the outcome was already known would be grossly unethical. In the TPPA the USA is seeking to strengthen this extension of monopoly privilege. Data exclusivity is to be for all undisclosed data, without any qualifiers; and the prohibition on use for marketing approval is now absolute for at least five years (Article E.16.1(a)). Data exclusivity is also to be extended, for at least three years, to variants of already approved products if new data are required to gain marketing approval (Article E.16.2). Limited exceptions are allowed to protect public health (Article E.16.3).

The USA also has a placeholder to seek similar data monopolies for biologics (Article E.20). Currently periods for such differential rights are specified as $0,5,8$ or 12 years, indicating the disagreement between parties. It has been suggested that the USA is seeking 12 years, but would settle for eight. ${ }^{65}$ There are complex issues involved in incentives for, and regulation of, biologics. Big Pharma argues that it is not possible to produce biosimilars for these drugs, because of the very different production process. If this is the case, then this raises questions about their patentability. Providing a clear description such that a skilled person can replicate the invention without undue experimentation is a fundamental condition of patent grant. If these products cannot be replicated, then they fail the patentability requirements. To date, only 13 biosimilar have been approved for marketing. ${ }^{66}$ Current regulatory processes require the replication of substantial clinical data, ${ }^{67}$ ensuring that there is a smaller price differential between biologic generics and generics for conventional drugs.

In the USA data exclusivity has turned the drug regulatory authority into a policing agent for patent holders - a policy known as patent linkage. The USA is seeking to introduce this controversial policy in the TPPA

\footnotetext{
${ }^{63}$ Article A.12 in the 2013 version and Article A.11 in the 2014 version.

${ }^{64}$ Article E.12 remains highly contested in the 2014 draft text. Australia agreed to such term extensions in AUSFTA, Article 17.9.8(a).

${ }^{65}$ Despite the fact that President Obama's 2014 budget proposed reducing US data exclusivity for biosimilars to seven years.

${ }^{66}$ Grant Thornton, Bio-dynamism - Insights into the Biosimilars market: An overall perspective, BioAsia 2013, p.19; ASHP Advantage e-Newsletter, Preparing for Biosimilars, February 2013, p.2. Hopsira has gained marketing approval in Australia for its biosimilar of filgrastim (Harris et al. 2013: 175).

${ }^{67}$ European Medicines Agency Guidelines for assessing biosimilars (http://www.tga.gov.au/pdf/euguide/chmp043704final.pdf).
} 
(Article E.17) as it has already done in bilateral trade agreements, starting with the 2001 trade agreement with Jordan, and including the AUSFTA. The data linkage provisions in the US-Jordan PTA are estimated to have raised pharmaceutical prices by 17 per cent (Abbott et al. 2012).

\subsection{Incentives and penalties}

TRIPS has only eight articles in section 5 on patents. The sole item in regard to penalties is the requirement for judicial review of any decision to revoke or forfeit a patent (Article 32).

In the TPPA the US - focusing as it does on the needs of rights-holders not of consumers or other innovating firms - is seeking increased penalties for infringement but no incentives to support high standards for patent grant.$^{68}$ Criminal penalties are to be provided for breaching trade secrecy rules (Article H.8.2) and each and every claim in a granted patent should be presumed valid, if there has been patent examination (Article H.2.3). In the US the presumption that a granted patent is valid creates a far more stringent test for proving patent invalidity than for proving infringement (Jaffe and Lerner 2004). As the US Federal Trade Commission noted in its 2002 review of the US patent system, "[a] plethora of presumptions and procedures tip the scales in favor of the ultimate issuance of a patent, once an application has been filed" (FTC 2003: 8). In Australia a patent application is presumed valid, and it is up to the patent examiner to disprove this. This reverse onus of proof is a major factor leading to the issue low quality patents (Moir 2013b). At present the presumption that a granted patent cannot be assumed to be valid is one of the few features of the patent system that does not favour patent owners. The already unbalanced system would become far more unbalanced if this proposal were agreed.

\subsection{Transparency and evaluation}

In Section 2.6 several proposals were put forward to introduce transparency, evaluation and audit into patent systems, thereby achieving a positive cycle of continuous policy improvement. The first of these proposals was a call for data on how patents are used.

There are no provisions in TRIPS addressing these issues. In the TPPA the US has called for the collection and analysis of statistical data - but only in respect of the infringement of patent privileges (Article H.3.2). The wording of the current draft of this article is almost identical to the wording in Article 12(2) of the 2011 leaked version and Article H.3.2 of the 2013 version. Article H.3(2) currently states that "Each Party recognizes the importance of collecting and analyzing statistical data and other relevant information concerning intellectual property rights infringements as well as the collecting information on best practices to prevent and combat infringements". The section in italics is identical to the 2011 version. ${ }^{69}$ This is very one-sided and again points directly to the authorship of this text - although it was presented by a government it was clearly drafted by patent-holders and shows none of the balance one expects from government text. What we desperately need are proper data on patent use and the costs of this use. Infringement is a minor issue in comparison.

\subsection{Miscellaneous other demands}

Beyond these key issues, which affect balance, efficiency and effectiveness in patent systems, the US patent ask includes a wide range of other aspects of patent policy. These demands usually involve detailed specifications on the relevant issue. They cover such matters as grace periods (self-publication within a 12 month period does not defeat novelty); how utility (industrial applicability) should be defined and how disclosure should operate. The proposed utility/industrial applicability standard is that used in the USA - a standard that is lower than that used in the lowest income of the negotiating partners, Vietnam (Public Citizen 2011). These detailed proscriptive specifications remind one of heavy-handed old-fashioned regulation. They specify processes that should be followed, rather than outcomes that should be achieved. As such they stifle innovation and improvement. They tie the hands of all future elected governments, at least in respect of these aspects of patent policy. As has been shown elsewhere (Weatherall 2014), such

\footnotetext{
${ }^{68}$ Though it does also seek improved efficiency in patent timeliness (Article E.XX.2), and increased sharing of data used to assess patent inventiveness (Article E.XX.3), both measures that principally benefit those seeking patent privileges.

${ }^{69}$ Except that "collecting" replaces "collection of".
} 
over-specification in copyright policy can limit a nation's options when dealing with new technologies and other circumstances.

\section{Conclusions}

The proposals put forward in this paper are designed to ensure that patent systems do what they are intended to do - encourage technological invention that would not otherwise take place. They are also designed to ensure that patent systems provide benefits to users of technology and discourage rentseeking behaviours. They are placed on the table to encourage debate and discussion about the fundamental principles needed to ensure patent systems operate to achieve their economic goals and meet the requirements of TRIPS Article 7 for the mutual advantage of producers and users of technological information and contributing to economic and social welfare.

Since their earliest days - the Paris Convention for the Protection of Industrial Property was signed in Paris in 1883 - international treaties on patents have been largely drafted with the interests of large business in mind. This has been most obvious with TRIPS and the later TRIPS-Plus treaties. These treaties have created substantial problems for small and medium sized businesses, for civil society and indeed for sovereign governments. Particular concerns have been raised by the health sector. ${ }^{70}$

The objective in this paper has been to identify a set of minimum standards which more closely reflect the interests of technology-importing economies, many of which are also developing economies. In such countries the imbalance of TRIPS and TRIPS-Plus rules are clear. There are few protections against rorting the patent system. Where national innovation capacity is low, this simply leads to transfers from consumers to foreign companies with no offsetting benefits. Foreign companies are able to acquire domestic monopolies without there being any commensurate spillover benefits to domestically-located firms. These revenues assist in transfer pricing allowing local subsidiaries of such companies to avoid paying a fair share of domestic taxation. Effectively, unless a patent system is redesigned along the lines proposed here, compliance with TRIPS means that large global patent-holding companies are able to extract substantial rents from the countries to which they send their patented products. There are no spillover benefits to offset the static efficiency losses.

Some one hundred years ago, when today's high income countries were developing, patents were far less frequently granted, were limited to genuine technological inventions and required more substantial inventiveness. They had a far less deadening effect on local innovation. It is ironic that as the pace of innovation has increased, and innovation has become a normal part of commercial life, the standards required to obtain a monopoly for such innovation have fallen to such very low levels. Apart from the injustice of forcing this neo-mercantilist set of regulatory rules on others, the TRIPS deal also appears to have been a Faustian bargain. In exchange for agreeing to these regulatory interventions to reduce competition and restrain trade developing nations expected to achieve better market access in textiles and agriculture and an end to "punitive measures under the U.S. Trade Act Section 301" (Scherer 2006: 39). The former were very slow in coming and the latter has still not occurred.

In the immediate post-TRIPS environment the EPO has played a large role in assisting economies new to the patenting world to establish patent offices. In doing this they have transferred mental models appropriate to European economies. Drahos considers that overseas aid in establishing local patent offices has integrated them "into a system of international patent administration in which the grant of low-quality patents by major patent offices is a daily occurrence" (Drahos 2008: 3). Drahos queries whether this model serves the interests of developing economies. But there is no off-the-shelf patent model that does serve the interests of developing economies - or even of technology-importing high income economies such as Australia, New Zealand or Singapore. This paper is a first step towards this goal.

\footnotetext{
${ }^{70}$ There is a vast literature on the obstacles to public health policy created by recent and proposed "trade" treaties. For an introduction to the health impacts of the TPPA see ANU seminar, A new generation of trade policy: maximising benefits for equity, nutrition and human health analysing the public health impacts of the TPPA (at public health and the TPPA. http://nceph.anu.edu.au/news-events/new-generation-trade-policy-maximising-benefits-equity-nutrition-and-human-health (11 October 2013).
} 
The first-best option would be that restraints on competition and trade not be included in "free trade" negotiations - they give free trade a bad name. Unfortunately this preferred option is now precluded by the outcome of the Uruguay Round. Post-TRIPS "trade" treaties are further reducing national sovereignty in managing domestic policy to support innovation.

As a second-best approach the set of principles outlined here would achieve the balance required by TRIPS Article 7. It would protect most nations from the worst effects of importing the dysfunctional patent systems currently in use in jurisdictions such as the USA, Australia and Europe. While the principal need for reform is in the critical areas of inventiveness and technology (what is patentable), no reform package will succeed unless it also addresses the substantial gaming behaviour encouraged by the current system. If the focus on semantics rather than substance is not addressed then other reforms will fail, for the very reasons the current system has become so unbalanced. Because patent policy is delivered through courts and quasi-courts it may become necessary to introduce additional elements to monitor court compliance with parliamentary objectives.

US demands in recent and current "trade" negotiations are simply designed to allow US patent-holders to extract large rents from foreign consumers as well as from US consumers. Unless and until Big Pharma places genuine financial data on the table demonstrating that it is unable to earn a commercial return on $R \& D / c l i n i c a l$ trial outlays, such proposals simply constitute rent-seeking. This is the real piracy - like that of Elizabethan days it is sanctioned by the State.

The most dangerous part of the USTR TPPA patent proposals is the footnote requiring all signatories to use the very low "is it obvious?" approach to assessing inventiveness. This is the doctrine that lies at the heart of the current very low inventiveness standard (Moir 2013b). Another particularly dangerous demand is proposed article E.1 that requires a rule encouraging evergreening by allowing the use of known things to be patented ("any new uses or methods of using a known product"). When a product is patented the patent owner is granted a very strong range of exclusionary privileges. To add to these by allowing further 20-year privileges for each use of the already patented product is double-dipping and a travesty of economic policy. It clearly indicates that the USTR agenda is rent-seeking and that there are no boundaries to their ambitions in extracting rents. These demands run directly counter to TRIPS Article 7 which requires balance between producers and users of technology.

These post-TRIPS treaties are highly regulatory. The attempt to dot every $i$ and cross every $t$ of current US patent administration ${ }^{71}$ and impose these detailed rules on other parties, at very different levels of economic and technological development. Indeed these treaties might better be referred to as "regulatory treaties" rather than "trade treaties", as the bulk of the documents are taken up with detailed rules as to how various aspects of domestic economic and regulatory policy will work. The newly released Canada-EU agreement (CETA) runs to 1,634 pages and has 42 chapters. This seems directed to facilitate the growth of lawyers, rather than of business.

Most of the benefit of a trade treaty arise from domestic reform (Armstrong 2012: 1641). It is the dismantling of barriers to competition that delivers the greatest economic benefit - a benefit spread throughout the economy, both to consumers and to other firms. The opening up of overseas markets benefits only a few firms, but does not create much benefit for the nation as a whole. Trade negotiations are too often dominated by lawyers and other non-economists who do not understand this.

Accepting a range of restrictive interventions to suppress competition in markets for innovation is a very high price to pay for small improvements in access to overseas markets. This is especially so as TRIPS includes a most favoured nation (MFN) clause which requires additional benefits granted to one party to be provided to all other TRIPS signatories. So the cost of these monopoly provisions extends not just to other signatories to the preferential agreement, but to all WTO members. The "intellectual property" costs tends to be ignored because the lack of policy-useful data means they are hard to quantify. It is clear, however, that the costs for pharmaceuticals alone are quite substantial. To prevent essential future economic reform, while unquantifiable, is a very substantial cost.

\footnotetext{
${ }^{71}$ In fact, as Flynn and colleagues (2012) point out, in some instances they go beyond current US patent policy.
} 
$\stackrel{\sim}{\sim}$

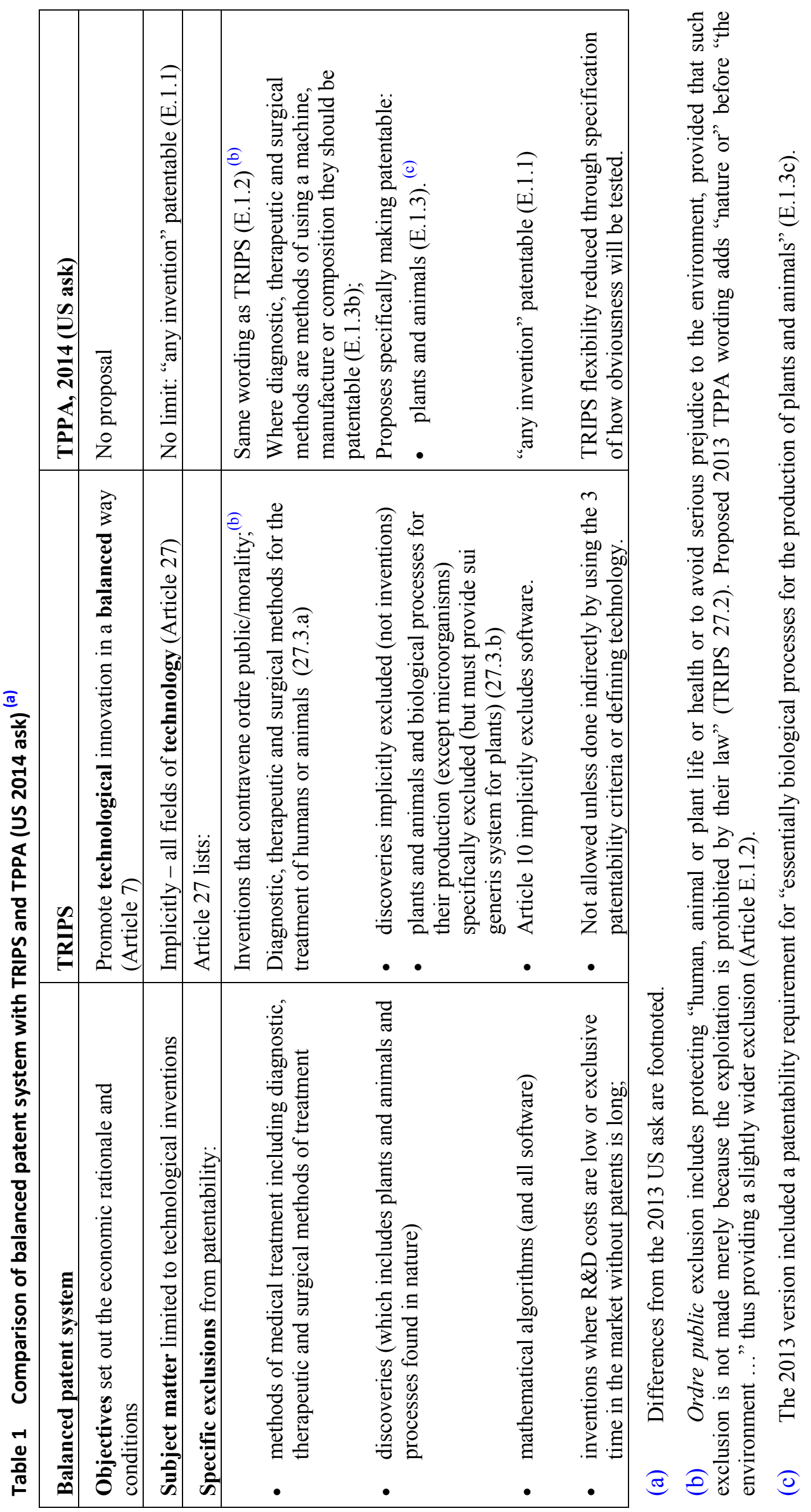


$\stackrel{n}{\sim}$

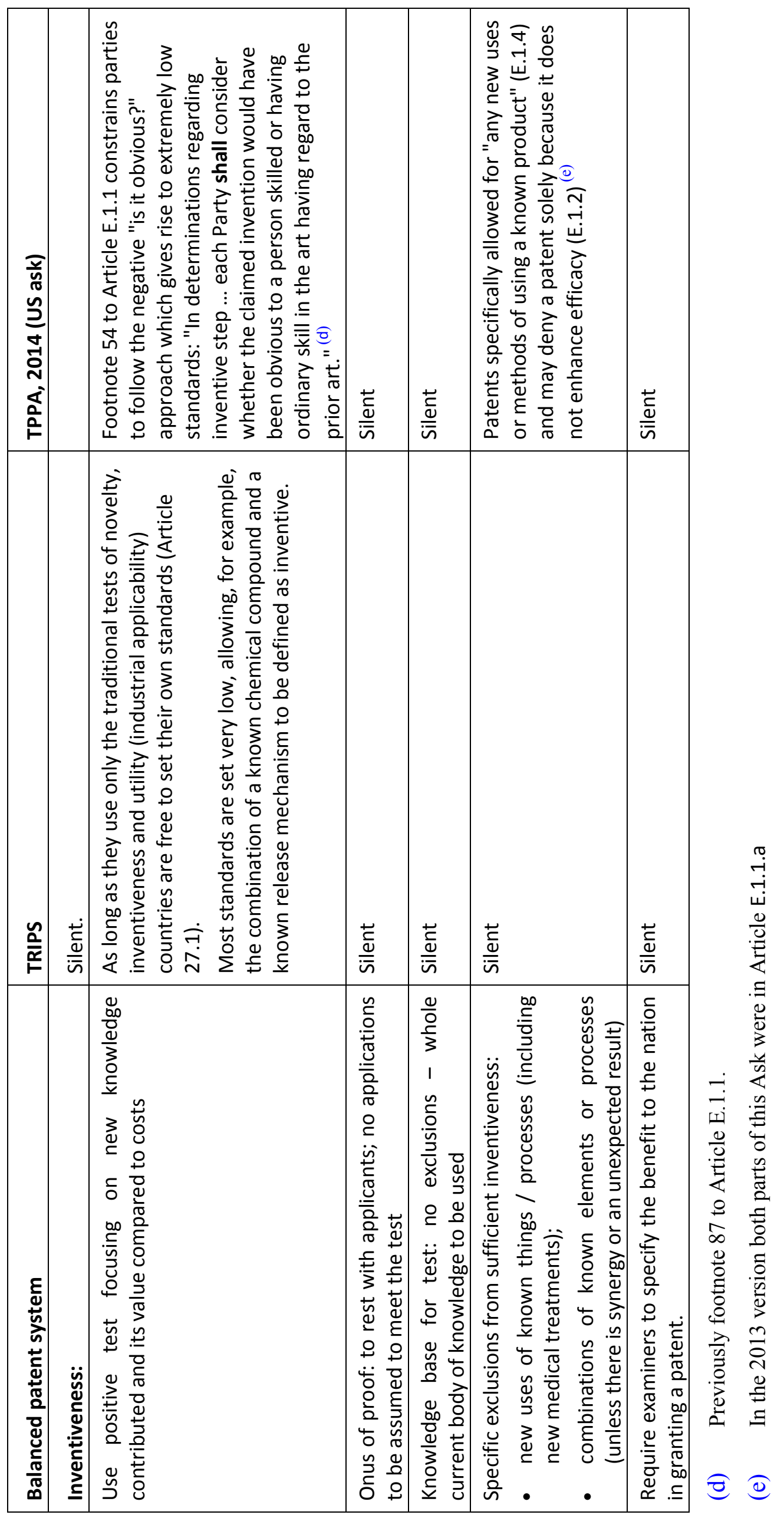


$\stackrel{\circ}{\sim}$

\begin{tabular}{|c|c|c|c|c|c|c|}
\hline 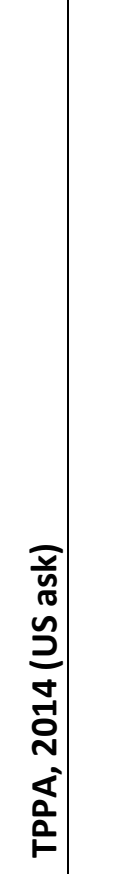 & 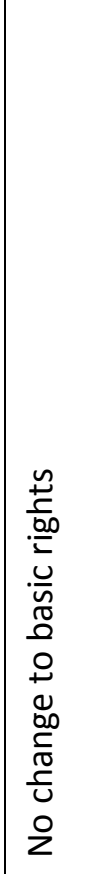 & 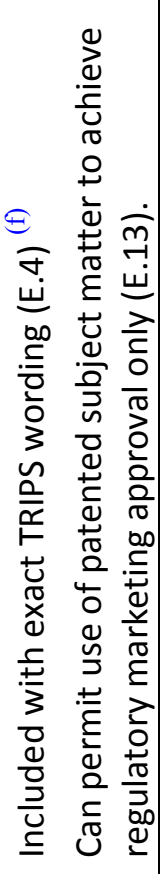 & $\begin{array}{l} \\
\\
+\frac{5}{0} \\
\frac{\omega}{5}\end{array}$ & 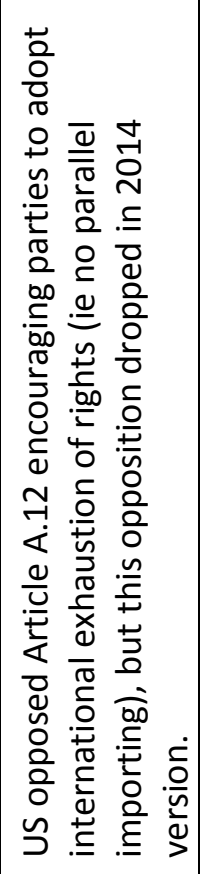 & 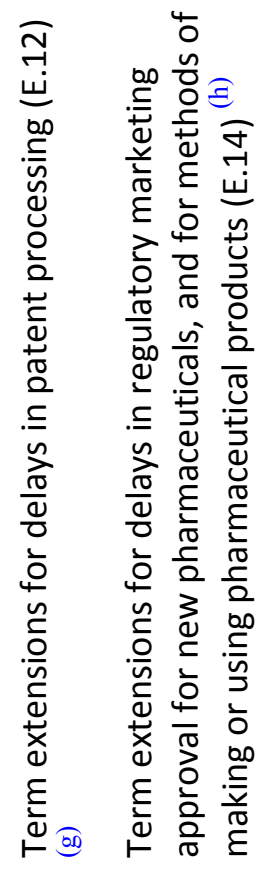 & 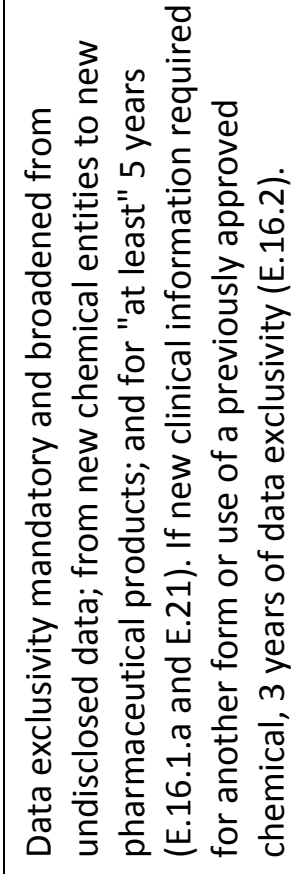 \\
\hline $\begin{array}{l}\check{\varrho} \\
\overline{\tilde{c}}\end{array}$ & 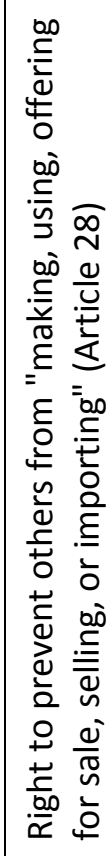 & 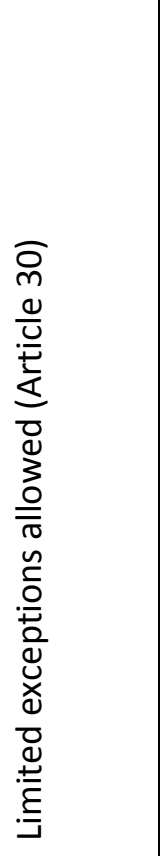 & 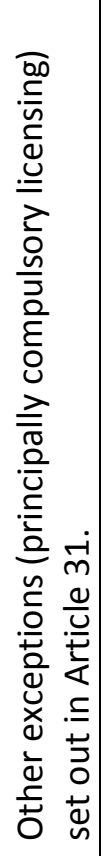 & 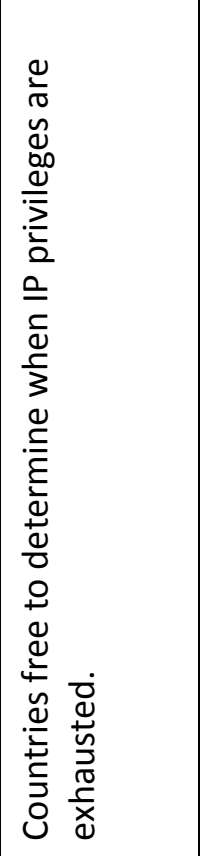 & 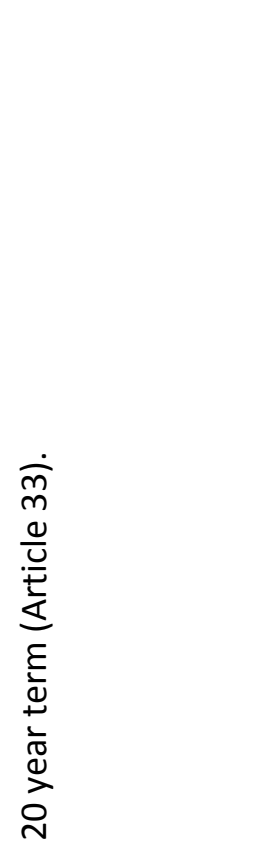 & 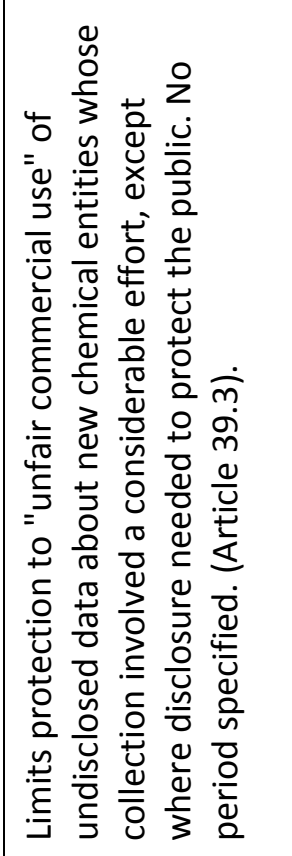 \\
\hline 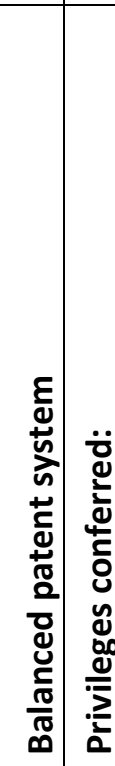 & 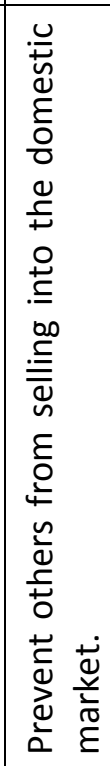 & & & 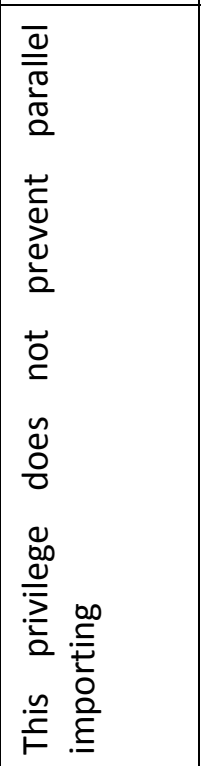 & 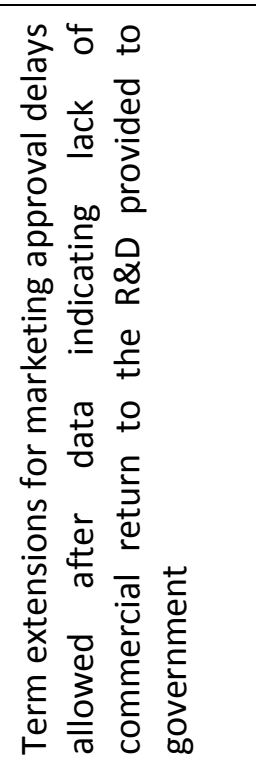 & 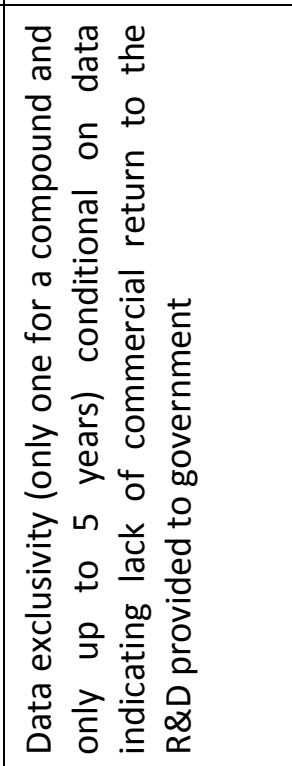 \\
\hline
\end{tabular}




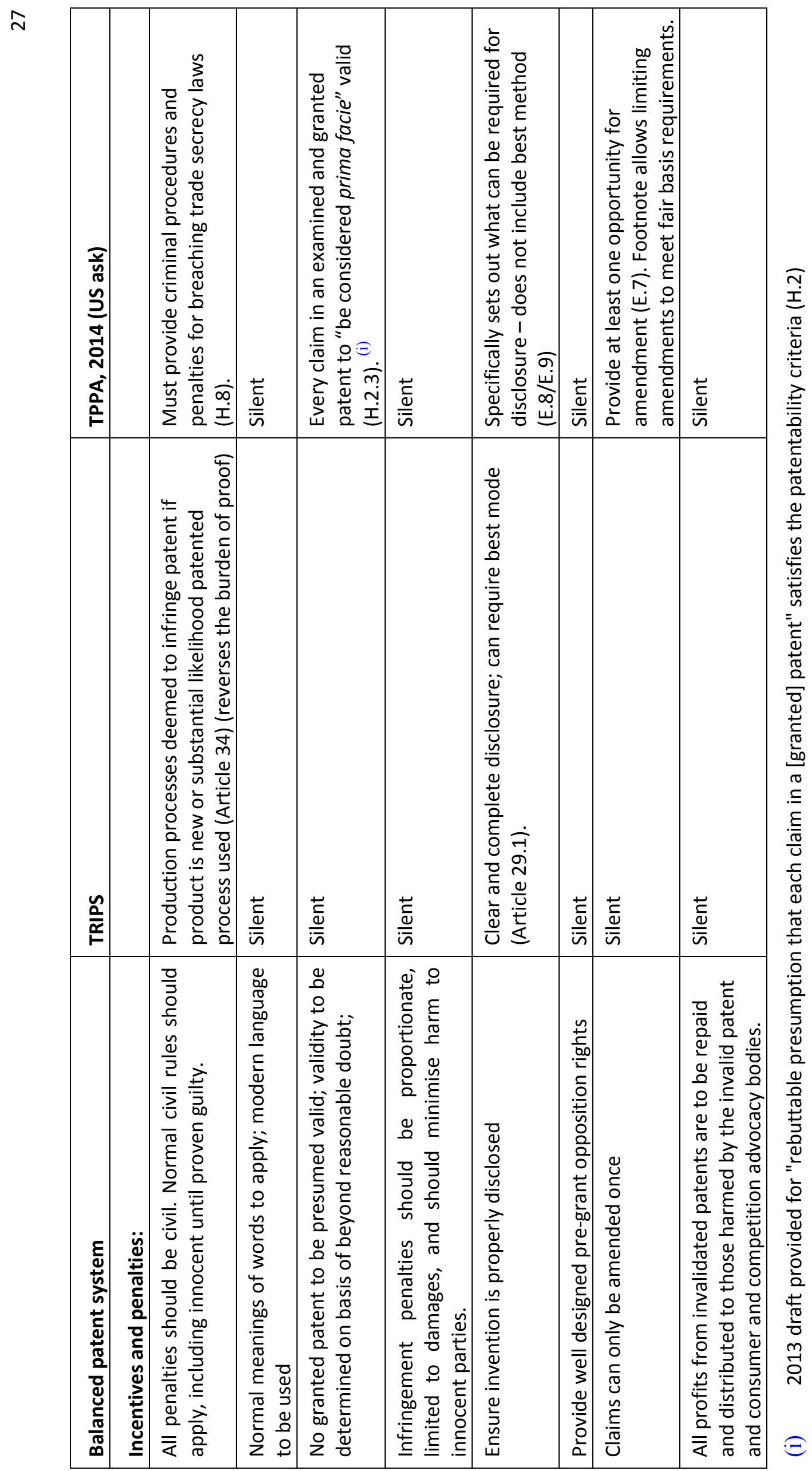


$\stackrel{\infty}{\sim}$

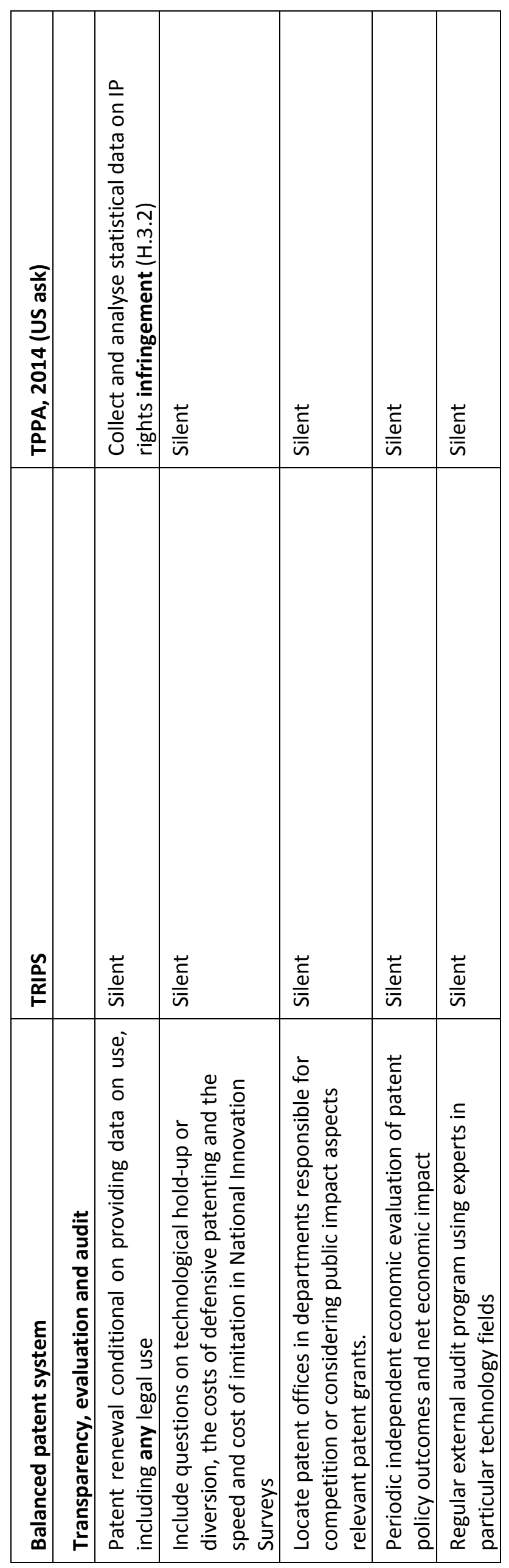


구

\begin{tabular}{|c|c|c|c|c|c|c|c|c|}
\hline 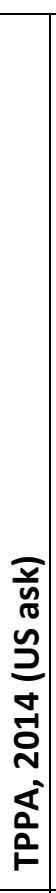 & 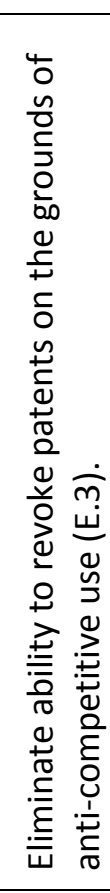 & 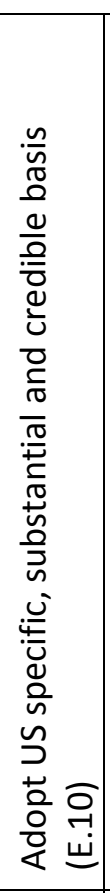 & 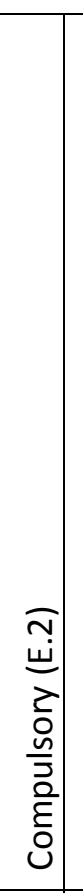 & 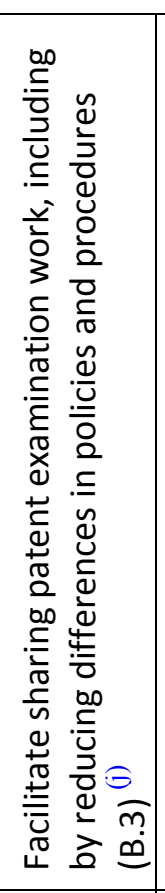 & 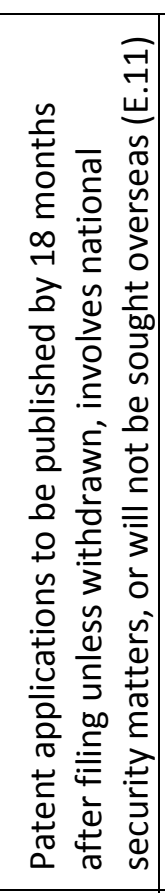 & 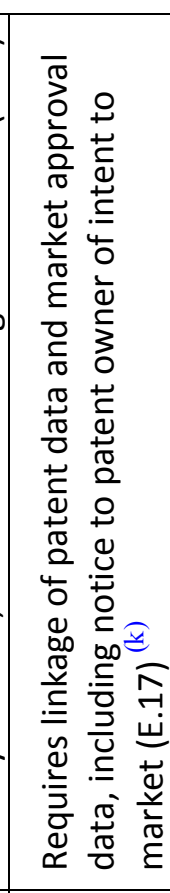 & 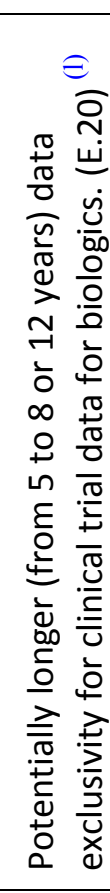 & 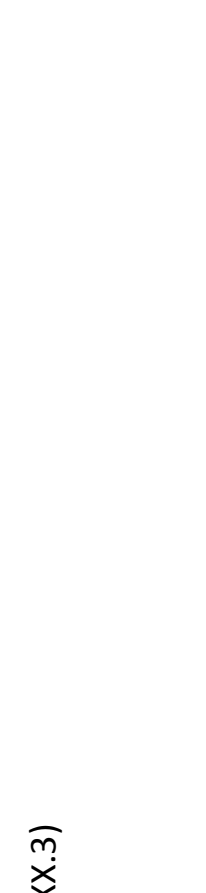 \\
\hline$\frac{\tilde{n}}{\tilde{\underline{\kappa}}}$ & 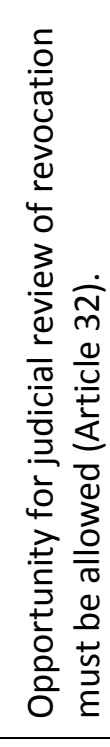 & 苞 & $\begin{array}{l}\frac{\vec{v}}{\omega} \\
\frac{\omega}{\bar{n}}\end{array}$ & 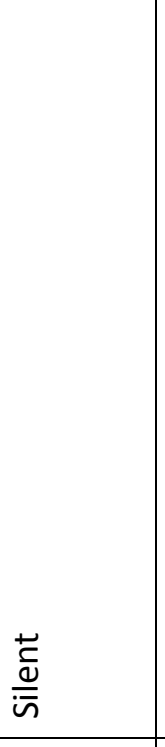 & 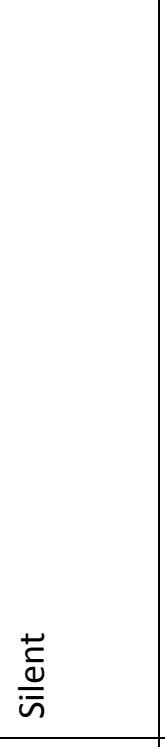 & 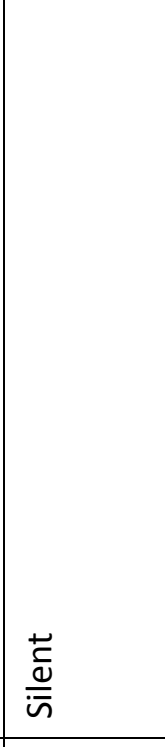 & 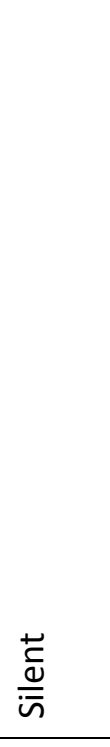 & 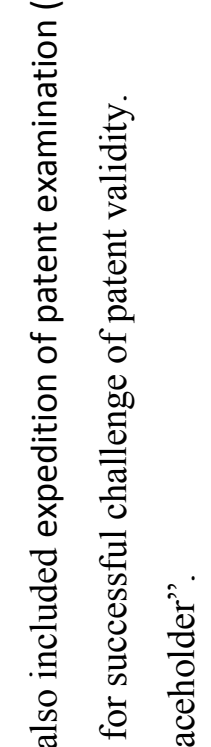 \\
\hline 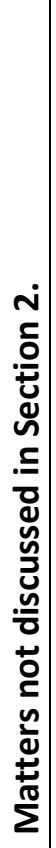 & 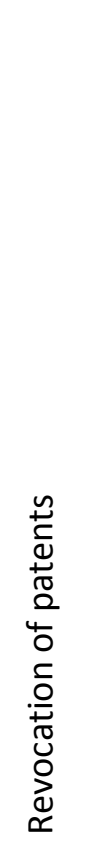 & 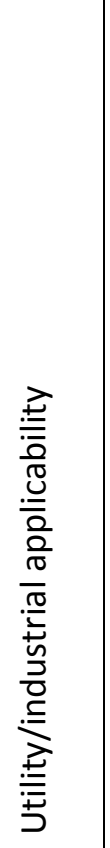 & 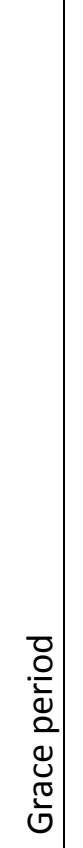 & 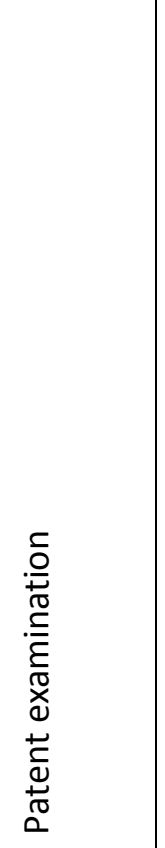 & 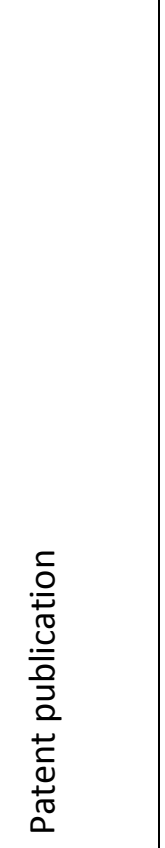 & 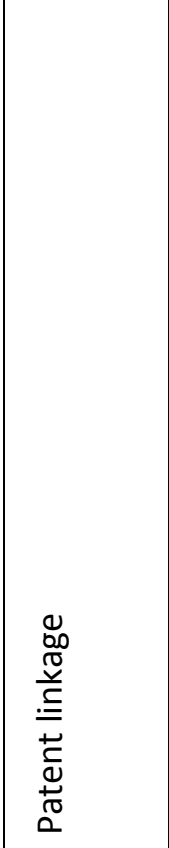 & $\begin{array}{l}\frac{\tilde{y}}{00} \\
\frac{0}{0} \\
\frac{0}{0}\end{array}$ & 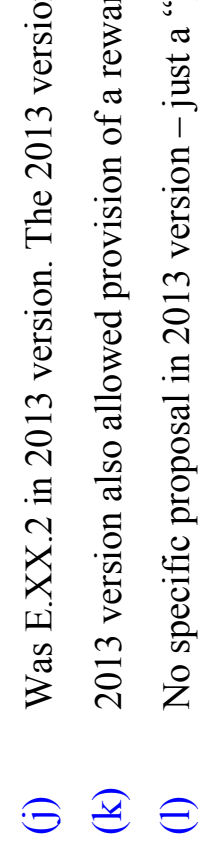 \\
\hline
\end{tabular}




\section{References}

Abbott, R.B., R. Badr, L. Bajjali, T.A. El Samen, T. Obeidat, H. Sboul, M. Shwayat, and I. Alabbadi (2012), 'The price of medicines in Jordan: the cost of trade-based intellectual property', Journal of Generic Medicines 9 (2): 75-85.

ACIP (2008), Patentable Subject Matter: Issues Paper, Canberra: Advisory Council on Intellectual Property. Armstrong, S. (2012), 'Australian Trade Policy Strategy Contradictions', The World Economy: 1633-1644.

Arrow, K.J. (1962), 'Economic welfare and the allocation of resources for invention', pp. 609-625 in NBER (eds), The Rate and Direction of Inventive Activity: Economic and Social Factors, Princeton

Attaran, A. and P. Champ (2002), 'Patent Rights and Local Working Under the WTO TRIPS Agreement: An Analysis of the U.S.-Brazil Patent Dispute', Yale Journal of International Law 27 (2): 365-393.

Bakels, R.B. (2012), The Technology Criterion in Patent Law:: A Controversial But Indespensible Requirement, The Netherlands: Wolf Legal Publishers.

Barton, J.H. (2000), 'Reforming the patent system', Science 287 (5460): 1933-1934.

Beggs, J. (1981), 'On the evaluation of the Australian patent system', pp. 39-44 in T.D. Mandeville, D.M. Lamberton, and E.J. Bishop (eds), The Economic Implications of Patents in Australia, Canberra: Australian Patent Office.

Bessen, J.E. and M.J. Meurer (2008), Patent Failure: How Judges, Bureaucrats, and Lawyers Put Innovators at Risk, Princeton and Oxford: Princeton University Press.

Blonder, G. (2005), 'Cutting through the patent thicket', Business Week, 19 December.

Boldrin, M. and D.K. Levine (2004), 'The case against intellectual monopoly', International Economic Review 45 (2): 327-350.

- (2008), Against Intellectual Monopoly, Cambridge: Cambridge University Press.

- (2013), 'The case against patents', Journal of Economic Perspectives 27 (1): 3-33.

Bonatti, L. and S. Comino (2011), 'The inefficiency of patents when R\&D projects are imperfectly correlated and imitation takes time', Journal of Institutional and Theoretical Economics 167 (2): 327-342.

Braithwaite, J. (2005), Markets in Vice, Markets in Virtue, Sydney: The Federation Press.

Branstetter, L.G., C. Chatterjee, and M. Higgins (2011), 'Regulation and Welfare: Evidence from Paragraph IV Generic Entry in the Pharmaceutical Industry', Working Paper 17188, National Bureau of Economic Research.

Burdon, M. and K. Sloper (2003), 'The Art of Using Secondary Patents to Improve Protection', Journal of Medical Marketing 3 (3): 226-238.

Chaudhuri, S., P. Goldberg, and P. Jia (2006), 'Estimating the Effects of Global Patent Protection in Pharmaceuticals: A Case Study of Quinolones in India', The American Economic Review 96 (5): 1477-1514.

Cutler, T., N. Gruen, M. O'Kane, S. Dowrick, N. Kennedy, G. Davis, C. Livingstone, M. Clark, J. Foster, J. Peacock, and P. Kelly (2008), venturousaustralia - building strength in innovation: Report on the Review of the National Innovation System, Canberra: Department of Innovation, Industry, Science and Research.

Drahos, P. (2008), '“Trust Me": Patent Offices in Developing Countries', American Journal of Law \& Medicine 34: 1-24.

- (2010), The Global Governance of Knowledge: Patent Offices and Their Clients, Cambridge: Cambridge University Press.

Dutta (2011), 'From Free Entry to Patent Protection: Welfare Implications for the Indian Pharmaceutical Industry', The Review of Economics and Statistics 93 (1): 160-178.

Edwards, C.D. (1949), Maintaining Competition: Requisites of a Governmental Policy, New York: McGrawHill.

European Commission (2009), Final Report: Competition Inquiry into the Pharmaceutical Sector, Brussels: European Commission.

Firestone, O.J. (1971), Economic Implications of Patents, Ottawa: University of Ottawa Press. 
Flynn, S., B.K. Baker, M. Kaminski, and J. Koo (2012), 'The U.S. proposal for an intellectual property chapter in the Trans-Pacific Partnership Agreement', American University International Law Review 28 (1): 105-202.

Frier, S. (2013), 'IBM Granted Most U.S. Patents for 20th Straight Year'. http://www.bloomberg.com/news/print/2013-01-10/ibm-granted-most-u-s-patents-for-20th-straightyear.html

FTC (2003), To Promote Innovation: The Proper Balance of Competition and Patent Law and Policy, Washington, D.C.: Federal Trade Commission (US).

Goldacre, B. (2012), Bad Pharma, London: Fourth Estate.

Hall, B.H. and R.H. Ziedonis (2001), 'The patent paradox revisited: an empirical study of patenting in the U.S. semiconductor industry, 1979-1995', RAND Journal of Economics 32 (1): 101-128.

Harris, T., D. Nicol, and N. Gruen (2013), Pharmaceutical Patents Review Report, Canberra, available at http://www.ipaustralia.gov.au/pdfs/2013-05-27_PPR_Final_Report.pdf:

Hirschman, A.O. (1977), The Passions and the Interests: Political Arguments for Capitalism before its Triumph, Princeton: Princeton University Press.

Holovac, M.A. (2004), 'A balancing act in the United States Drug Industry: pioneer and generic drugs, the Orange Book, marketing protection and the US consumer', World Patent Information 26: 123-129.

IP Australia (2013), 'Australian Intellectual Property Report 2013', Canberra:

IPAC (1984), Patents, Innovation and Competition in Australia, Canberra: Industrial Property Advisory Committee (now available at http://www.acip.gov.au/reviews_other.html).

Jaffe, A.B. and J. Lerner (2004), Innovation and its Discontents: How Our Broken Patents System is Endangering Innovation and Progress, and What to Do About It, Princeton: Princeton University Press.

Jensen, P.H. and E.M. Webster (2004), 'Achieving the optimal power of patent rights', The Australian Economic Review 37 (4): 419-426.

Kahin, B. (2003), 'Information process patents in the US and Europe: policy avoidance and policy divergence', First Monday 8 (3).

Koenig, G.K. (1980), Patent Invalidity: A Statistical and Substantive Analysis, New York: Clark Boardman.

Lawson, C. (2008), 'Quantum of obviousness in Australian patent laws', Australian Intellectual Property Journal 19: 43-65.

Levin, R.C., A.K. Klevorick, R.R. Nelson, and S.G. Winter (1987), 'Appropriating the returns from industrial research and development', Brookings Papers on Economic Activity, Special Issue on Microeconomics 1987 (3): 783-831.

Light, D.W. and R. Warburton (2011), 'Drug R\&D costs questioned', Genetic Engineering and Biotechnology News: 6-7.

López, A. (2009), 'Innovation and appropriability: empirical evidence and research agenda', pp. 1-32 in WIPO (eds), The Economics of Intellectual Property: Suggestions for Further Research in Developing Countries and Economies in Transition: WIPO.

Lunney, G.S., Jr. (2004), 'Patent law, the Federal Circuit, and the Supreme Court: a quiet revolution', Supreme Court Economic Review 11: 1-79.

Lunney, G.S., Jr. and C.T. Johnson (2012), 'Not so obvious after all: patent law's nonobviousness requirement, KSR, and the fear of hindsight bias', Georgia Law Review 47 (1): 41-111.

Machlup, F. (1958), An Economic Review of the Patent System (Study No.15 of the U.S. Senate Subcommittee on Patents, Trademarks and Copyrights), Washington, D.C.: US Government Printing Office.

Mansfield, E., M. Schwartz, and S. Wagner (1981), 'Imitation costs and patents: an empirical study', The Economic Journal 91 (364): 907-918.

Mercurio, B. and M. Tyagi (2010), 'Treaty Interpretation in WTO Dispute Settlement: The Outstanding Question of the Legality of Local Working Requirements", Minnesota Journal of International Law 19 (2): 275-326. 
Moir, H.V.J. (2008), 'Who benefits? an empirical analysis of Australian and US patent ownership' paper presented at European Consortium for Political Research (ECPR), Workshop 14, The Politics of Intellectual Property, Rennes: http://hdl.handle.net/1885/9504

- (2013a), 'Empirical evidence on the inventive step', European lintellectual Property Review April.

Moir, H.V.J. (2013b), 'Fabricating invention: the patent malfunction of Australian patent law', Agenda 20 (2): 21-38.

Moir, H.V.J. (2013c), Patent Policy and Innovation: Do Legal Rules Deliver Effective Economic Outcomes?, Cheltenham, UK: Edward Elgar.

Moir, H.V.J. and L. Palombi (2013), 'Patents and Trademarks: empirical evidence on 'evergreening' from Australia' paper presented at 4th Asia-Pacific Innovation Conference, National Taiwan University, Taipei:

Moser, P., J. Ohmstedt, and P.W. Rhode (2013), 'Patent Citations and the Size of Patented Inventions Evidence from Hybrid Corn', Available at SSRN: http://ssrn.com/abstract=1888191

New Zealand Ministry of Economic Development (2002), Review of the Patents Act 1953: Boundaries to Patentability: A Discussion Paper, Wellington, available at http://www.med.govt.nz/business/intellectualproperty/pdf-docs-library/patents/review-of-patents-act/boundaries-to-patentability/review-of-thepatents-act-1953-boundaries-to-patentability-pdf

Pilch, H. (2003), 'Why are software patents so trivial?' paper presented at OECD Intellectual Property Rights (IPR), Innovation and Economic Performance Conference, Paris: OECD.

Public Citizen (2011), Vietnam and the Trans-Pacific Partnership Agreement Access to Medicines Risks for a PEPFAR Partner, 16 June.

Quillen Jr., C.D. (2006), 'Innovation and the U.S. patent system', Virginia Law and Business Review 1: 210225.

- (2008), 'Commentary on Bessen and Meurer's Patent Failure: an industry perspective', Journal of Intellectual Property Law 16: 57-81.

Ruse-Khan, H.G. (2014), 'Principles for intellectual property provisions in bilateral and regional agreements', European Intellectual Property Review 36 (4): 207-211.

Scherer, F.M. (2006), The Political Economy of Patent Policy Reform in the United States, Washington, D.C.: AEI-Brookings Joint Center for Regulatory Studies.

Thadikkaran, M. (2013), 'Local Working Requirement: Reconciling TRIPS Agreement with the Paris Convention', Global trade and Customs Journal 8 (1): 18-.

Thambisetty, S. (2009), Increasing returns in the patent system: institutional sources and consequences for law London: LSE Law, Society and Economy Working Papers 7/2009.

- (2014), 'Novartis $v$ Union of India and the person skilled in the art: a missed opportunity', Law, Society and Economy Working Paper 2/2014, London School of Economics.

Wagner, S. (2008), 'Business method patents in Europe and their strategic use - evidence from franking device manufacturers', Economics of Innovation and New Technology 17 (3): 173-194.

Weatherall, K. (2014), 'AUSFTA'S influence over Australia's copyright trade policy' paper presented at Ten years since the Australia-US Free Trade Agreement: Where to for Australia's Trade Policy?, Sydney, UNSW: ASSA / UNSW. 